\title{
Boron-10 ABUNCL Prototype Initial Testing
}

Richard T. Kouzes

James H. Ely

Azaree T. Lintereur

Edward R. Siciliano

December 2012

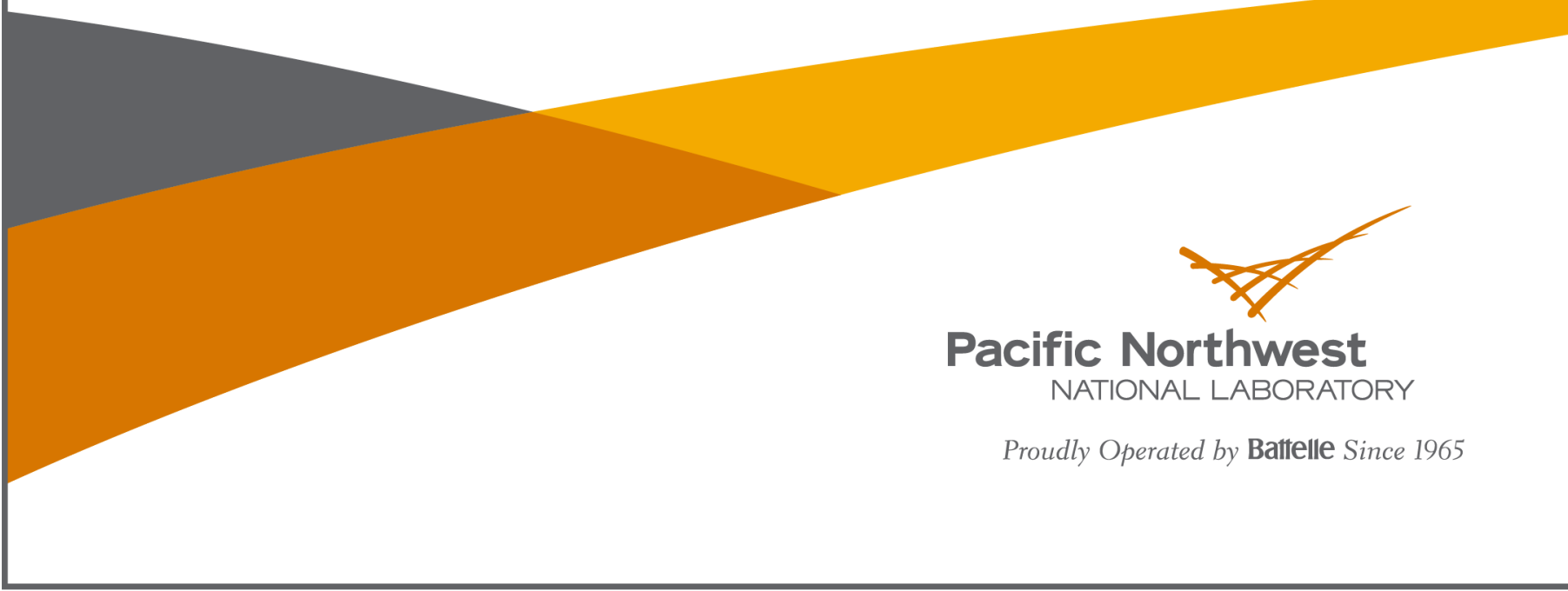




\title{
DISCLAIMER
}

This report was prepared as an account of work sponsored by an agency of the United States Government. Neither the United States Government nor any agency thereof, nor Battelle Memorial Institute, nor any of their employees, makes any warranty, express or implied, or assumes any legal liability or responsibility for the accuracy, completeness, or usefulness of any information, apparatus, product, or process disclosed, or represents that its use would not infringe privately owned rights. Reference herein to any specific commercial product, process, or service by trade name, trademark, manufacturer, or otherwise does not necessarily constitute or imply its endorsement, recommendation, or favoring by the United States Government or any agency thereof, or Battelle Memorial Institute. The views and opinions of authors expressed herein do not necessarily state or reflect those of the United States Government or any agency thereof.

\author{
PACIFIC NORTHWEST NATIONAL LABORATORY \\ operated by \\ BATTELLE \\ for the \\ UNITED STATES DEPARTMENT OF ENERGY \\ under Contract DE-AC05-76RL01830
}

Printed in the United States of America
Available to DOE and DOE contractors from the
Office of Scientific and Technical Information,
P.O. Box 62, Oak Ridge, TN 37831-0062;
ph: (865) 576-8401
fax: (865) 576-5728
email: reports@adonis.osti.gov

Available to the public from the National Technical Information Service, U.S. Department of Commerce, 5285 Port Royal Rd., Springfield, VA 22161

ph: (800) 553-6847

fax: (703) 605-6900

email: orders@ntis.fedworld.gov

online ordering: http://www.ntis.gov/ordering.htm 
PNNL-22147

\section{Boron-10 ABUNCL Prototype Initial Testing}

Richard T. Kouzes

James H. Ely

Azaree T. Lintereur

Edward R. Siciliano

December 2012

Pacific Northwest National Laboratory

Richland, Washington 99352 


\section{Executive Summary}

The Department of Energy Office of Nuclear Safeguards and Security (NA-241) is supporting the project Coincidence Counting With Boron-Based Alternative Neutron Detection Technology at Pacific Northwest National Laboratory (PNNL) for the development of a ${ }^{3} \mathrm{He}$ proportional counter alternative neutron coincidence counter. The goal of this project is to design, build and demonstrate a system based upon ${ }^{10} \mathrm{~B}$-lined proportional tubes in a configuration typical for ${ }^{3} \mathrm{He}-$ based coincidence counter applications.

This report provides results of initial testing of an Alternative Boron-Based Uranium Neutron Coincidence Collar (ABUNCL) design built by General Electric Reuter-Stokes. Several configurations of the ABUNCL models, which use ${ }^{10} \mathrm{~B}$-lined proportional counters in place of ${ }^{3} \mathrm{He}$ proportional counters for the neutron detection elements, were previously reported. The ABUNCL tested is of a different design than previously modeled. Initial experimental testing of the as-delivered passive ABUNCL was performed, and modeling will be conducted. Testing of the system reconfigured for active testing will be performed in the near future, followed by testing with nuclear fuel.

The efficiency determined from a measurement of a centered ${ }^{252} \mathrm{Cf}$ source was found to be $11.6(3) \%$. This is compared to a value reported by GE Reuter-Stokes of $12.1 \%$. The die-away time was found to be $75.2 \mu \mathrm{s}$. This die-away time is compared to a value reported by GE ReuterStokes of $65.6 \mu$ s [McKinny 2012]. Combining the efficiency and die-away time gives a FOM $\left(\varepsilon^{2} / \tau\right)$ of 1.8 , compared to the number reported by GE Reuter-Stokes of 2.23 [McKinny 2012]. 


\section{Acronyms and Abbreviations}

\begin{tabular}{ll} 
ABUNCL & Alternative Boron-Based Uranium Neutron Coincidence Collar \\
AmLi & Americium-lithium neutron source \\
BWR & Boiling water reactor \\
cps & Counts per second \\
DOE & U.S. Department of Energy \\
$\varepsilon$ & Detection efficiency \\
FOM & Figure of Merit \\
GE & General Electric \\
HDPE & High Density Polyethylene \\
IAEA & International Atomic Energy Agency \\
LEC & Low-Energy Cutoff \\
MCA & Multi-Channel Analyzer \\
MOX & Mixed Oxide fuel \\
NIM & Nuclear Instrumentation Module \\
PHL & Pulse-Height Light \\
PNNL & Pacific Northwest National Laboratory \\
Pu & Plutonium \\
$\tau$ & Die-away time \\
TTL & Transistor-transistor logic \\
U & Uranium \\
UNCL & Uranium Neutron Coincidence Collar \\
\hline
\end{tabular}




\section{Contents}

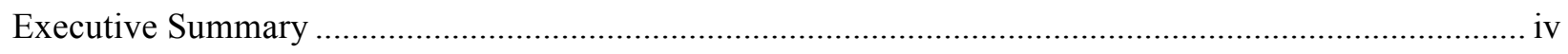

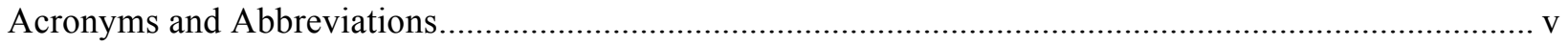

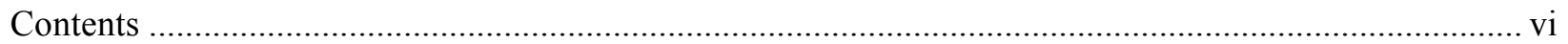

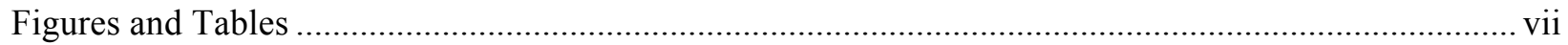

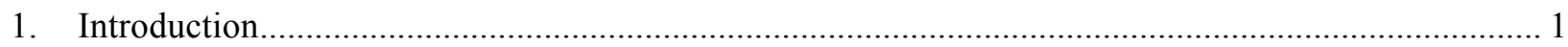

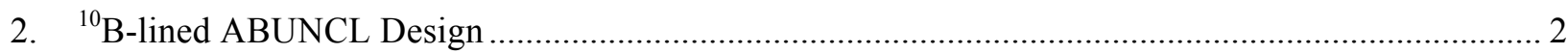

3. ${ }^{10} \mathrm{~B}$-lined ABUNCL Module Testing ........................................................................................ 7

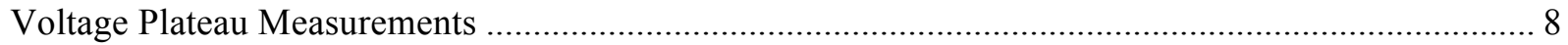

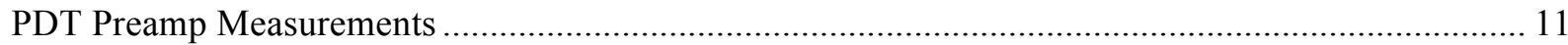

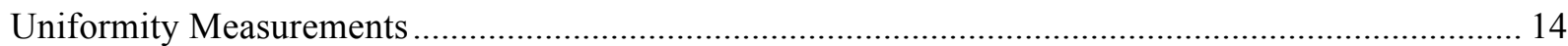

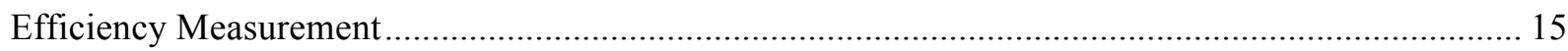

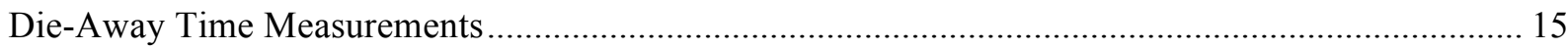

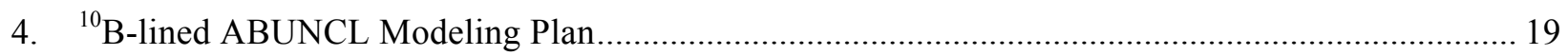

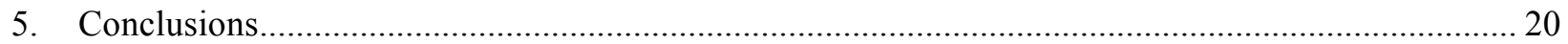

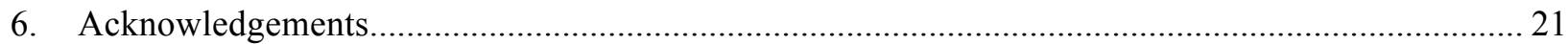

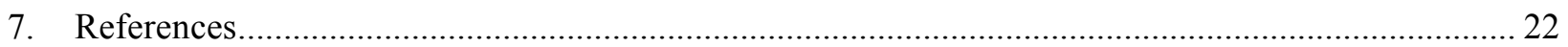




\section{Figures and Tables}

\section{Figures}

Figure 2.1. Canberra JCC-71 UNCL in Passive Configuration [Canberra 2011].................................... 2

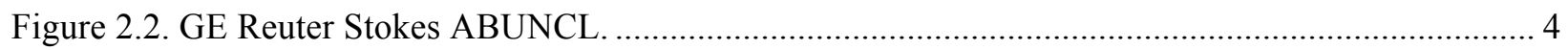

Figure 2.3. GE Reuter Stokes ABUNCL vertical cross-section (dimensions in inches).......................... 5

Figure 2.4. GE Reuter Stokes ABUNCL horizontal cross-section (dimensions in inches)........................ 6

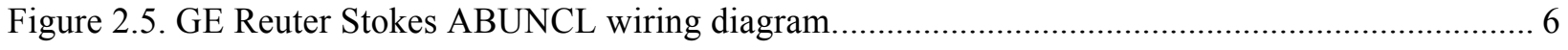

Figure 3.1. GE Reuter Stokes ABUNCL set up at PNNL. ................................................................. 7

Figure 3.2. Voltage plateau measurements for the three detector groups (right, middle, left) in Section 1. 8

Figure 3.3. Voltage plateau measurements for the two detector groups (left and right) in Section 2......... 9

Figure 3.4. Voltage plateau measurements for the three detector groups (left, middle, right) in Section 3. 9

Figure 3.5. Voltage plateau measurements for the two detector groups (left and right) Section 4............ 10

Figure 3.6. Source used for performing voltage plateau measurements................................................ 11

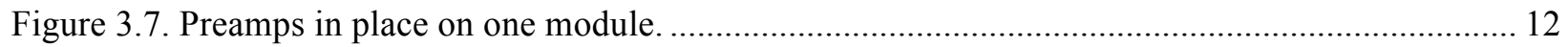

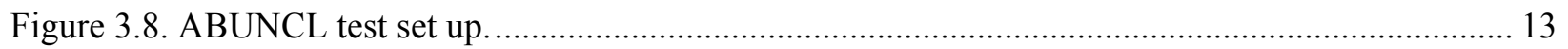

Figure 3.9. Energy spectrum from section $3 \mathrm{M}$ gated on threshold..................................................... 14

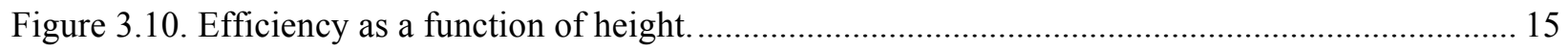

Figure 3.11. Dependence of real and accidental rates on gate width................................................... 17

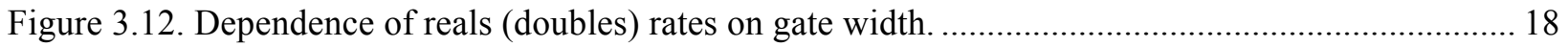

\section{Tables}

Table 2.1. Characteristics of the UNCL and ABUNCL configurations. .............................................. 3

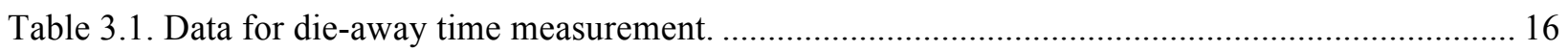

Table 5.1. Characteristics of the UNCL and ABUNCL configurations............................................... 20 


\section{Introduction}

The search for technological alternatives to ${ }^{3} \mathrm{He}$ is a major research area in nuclear security and safeguards due to the shortage of this gas in recent years [Kouzes 2010; Menlove 2011]. One of the important safeguards applications of ${ }^{3} \mathrm{He}$ has been for coincidence counting instruments. Coincidence counting is a high-precision technique used to measure the mass of plutonium $(\mathrm{Pu})$ or uranium (U) in samples [PANDA 1991]. For example, the Uranium Neutron Coincidence Collar (UNCL) is used by the International Atomic Energy Agency (IAEA) for verification of the mass of ${ }^{235} U$ in low-enriched $U$ fuel assemblies [Menlove 1981; Menlove 1990].

The Department of Energy Office of Nuclear Safeguards and Security (NA-241) is supporting the project Coincidence Counting With Boron-Based Alternative Neutron Detection Technology at Pacific Northwest National Laboratory (PNNL) for the development of a ${ }^{3} \mathrm{He}$ proportional counter alternative neutron coincidence counter. The goal of this project is to design, build and demonstrate a system based upon ${ }^{10} \mathrm{~B}$-lined proportional tubes in a configuration typical for ${ }^{3} \mathrm{He}-$ based coincidence counter applications. Under this project, PNNL has delivered a number of reports on coincidence counting, including an overview [Kouzes 2012], model validation [Lintereur 2012; Rogers 2012], wall effect models [Siciliano 2012], and models of ${ }^{3} \mathrm{He}-$ based UNCL systems [Siciliano 2012b]. A modeling study of the Alternative Boron-Based Uranium Neutron Coincidence Collar (ABUNCL) determined design parameters for a boron-based alternative to the UNCL [Rogers 2012b].

General Electric (GE) Reuter-Stokes (Twinsburg, $\mathrm{OH}$ ) has developed a coincidence collar based on arrays of ${ }^{10} \mathrm{~B}$-lined tubes that has been loaned to PNNL for testing against the safeguards requirements for an ABUNCL. The GE Reuter Stokes ABUNCL is configured in a passive UNCL design for making measurements of fresh Pu-based [mixed oxide (MOX)] fuel.

The testing this prototype includes source-based testing of the current passive mode configuration. Since the ABUNCL will be used for measuring uranium-based fresh fuels, an active configuration is required. The GE Reuter Stokes system will thus be modified for active use, and following characterization measurements, it will be tested with fuel. 


\section{2. ${ }^{10} \mathrm{~B}$-lined ABUNCL Design}

The GE Reuter-Stokes ABUNCL design derives from a cooperative effort between GE ReuterStokes and Canberra Industries, Inc. (Meriden, $\mathrm{CN}$ ) and is based on the Canberra JCC-71 models [Canberra 2011]. An example of a Canberra JCC-71 (passive UNCL-I for PWR fuel) is shown in Figure 2.1.

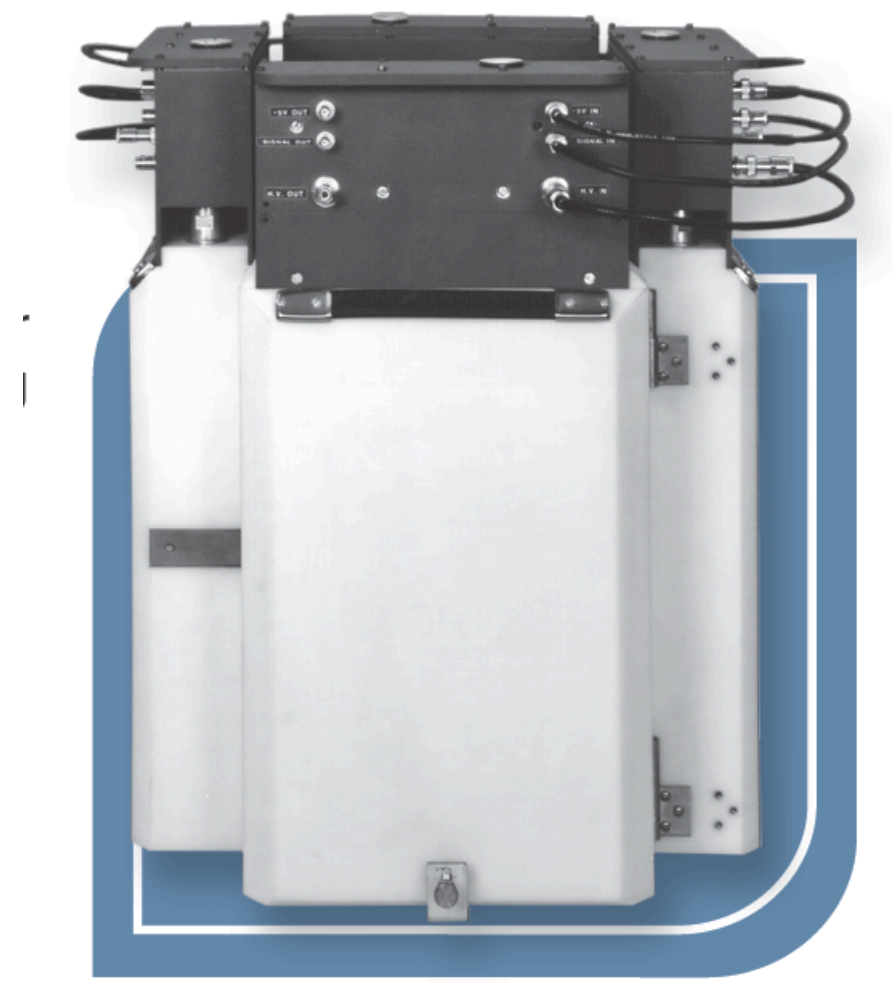

Figure 2.1. Canberra JCC-71 UNCL in Passive Configuration [Canberra 2011].

Figure 2.2 shows a photograph of the GE Reuter-Stokes ABUNCL assembly being tested in their laboratory. It consists of multiple boron-lined tubes held in four high-density polyethylene (HDPE) slabs joined together in a cube. Individual slabs can be removed from the assembly. The assembly has external dimensions of $35 \mathrm{~cm} \mathrm{x} 49 \mathrm{~cm}$ x $81 \mathrm{~cm}$, cavity dimensions of $16.5 \mathrm{~cm} \mathrm{x}$ $23.4 \mathrm{~cm}$, and a total mass of $77 \mathrm{~kg}$. The preamplifiers (PDT10A/20A) used in the ABUNCL are manufactured by Precision Data Technology, Inc. (Everett, WA).

Thus, the system is configured as a passive boiling water reactor (BWR) coincidence collar. Table 2.1 shows modeled $^{1}$ and, when available, measured characteristics of UNCL systems [Siciliano 2012b], one of the PNNL designs for an ABUNCL system [Rogers 2012b], and the GE Reuter-Stokes ABUNCL system [McKinny 2012].

\footnotetext{
${ }^{1}$ All modeling results referenced in this report were performed using the Monte Carlo N-Particle (MCNPX) [Pelowitz 2011] code,
} 
Table 2.1. Characteristics of the UNCL and ABUNCL configurations.

\begin{tabular}{|c|c|c|c|c|c|c|c|c|}
\hline \multirow{3}{*}{ Detector } & \multirow{3}{*}{$\begin{array}{c}\text { Total \# Tubes, } \\
\text { Configuration, \& } \\
\text { Fuel Cavity } \\
\text { H x L x W (cm) }\end{array}$} & \multirow{3}{*}{$\begin{array}{c}\text { Total } \\
\text { No. } \\
\text { Moles }\end{array}$} & \multicolumn{6}{|c|}{ Efficiency $(\varepsilon)$, Die-Away Time $(\tau) \&$ FOM $=\varepsilon^{2} / \tau$} \\
\hline & & & \multicolumn{3}{|c|}{ Measurement Results } & \multicolumn{3}{|c|}{ Model Results } \\
\hline & & & $\boldsymbol{\varepsilon}$ & $\tau(\mu s)$ & $\begin{array}{c}\text { FOM } \\
(\%)^{2} / \mu \mathrm{s}\end{array}$ & $\boldsymbol{\varepsilon}$ & $\tau(\mu s)$ & $\begin{array}{c}\text { FOM } \\
(\%)^{2} / \mu \mathrm{s}\end{array}$ \\
\hline $\begin{array}{l}\text { UNCL-I } \\
\text { Active } \\
\text { BWR }\end{array}$ & $\begin{array}{l}18^{3} \text { He tubes } \\
3 \text { Rectangular banks, } \\
41.4 \times 16.5 \times 23.4\end{array}$ & 0.44 & $13.5 \% * * *$ & & & $12.5 \%$ & 50 & 3.1 \\
\hline $\begin{array}{l}\text { UNCL-I } \\
\text { Active } \\
\text { PWR }\end{array}$ & $\begin{array}{l}18^{3} \text { He tubes } \\
3 \text { Rectangular banks } \\
41.4 \times 23.4 \times 23.4\end{array}$ & 0.44 & $10.3 \% * * *$ & & & $9 \%$ & 49 & 1.7 \\
\hline $\begin{array}{l}\text { UNCL-I } \\
\text { Passive } \\
\text { BWR }\end{array}$ & $\begin{array}{l}24{ }^{3} \text { He tubes } \\
4 \text { Rectangular banks } \\
41.4 \times 16.5 \times 23.4\end{array}$ & 0.59 & & & & $16.3 \%$ & 51 & 5.2 \\
\hline $\begin{array}{l}\text { UNCL-I } \\
\text { Passive } \\
\text { PWR }\end{array}$ & $\begin{array}{l}24{ }^{3} \text { He tubes } \\
4 \text { Rectangular banks } \\
41.4 \times 23.4 \times 23.4\end{array}$ & 0.59 & $\begin{array}{c}11.5 \% \\
( \pm 10 \%)^{\#}\end{array}$ & $\sim 51 *$ & 2.6 & $12.2 \%$ & 50 & 3.0 \\
\hline $\begin{array}{l}\text { UNCL-II } \\
\text { Active } \\
\text { BWR }\end{array}$ & $\begin{array}{l}16{ }^{3} \text { He tubes } \\
3 \text { Rectangular banks } \\
41.3 \times 16.5 \times 16.5\end{array}$ & 0.39 & $\begin{array}{c}15.3 \% * * \\
15.4 \% * * * \\
13.5 \% \\
( \pm 10 \%)\end{array}$ & $58 * *$ & 4.0 & $14.9 \%$ & 53 & 4.2 \\
\hline $\begin{array}{l}\text { UNCL-II } \\
\text { Active } \\
\text { PWR }\end{array}$ & $\begin{array}{l}20{ }^{3} \mathrm{He} \text { tubes } \\
3 \text { Rectangular banks } \\
41.3 \times 23.5 \times 23.5\end{array}$ & 0.49 & $\begin{array}{c}12.6 \% * * * \\
12.5 \% \\
( \pm 10 \%)^{\# \# \#}\end{array}$ & & & $12.3 \%$ & 53 & 2.9 \\
\hline $\begin{array}{l}\text { UNCL-II } \\
\text { Passive } \\
\text { BWR }\end{array}$ & $\begin{array}{l}20{ }^{3} \mathrm{He} \text { tubes } \\
4 \text { Rectangular banks } \\
41.3 \times 16.5 \times 16.5\end{array}$ & 0.49 & $\mathrm{NA}^{* * * *}$ & & & $19.1 \%$ & 54 & 6.8 \\
\hline $\begin{array}{l}\text { UNCL-II } \\
\text { Passive } \\
\text { PWR }\end{array}$ & $\begin{array}{l}26^{3} \mathrm{He} \text { tubes } \\
4 \text { Rectangular banks } \\
41.3 \times 23.5 \times 23.5\end{array}$ & 0.64 & $\mathrm{NA} * * * *$ & & & $16.3 \%$ & 53.1 & 5.0 \\
\hline $\begin{array}{l}\text { PNNL } \\
\text { ABUNCL } \\
\text { Active } \\
\text { BWR }\end{array}$ & $\begin{array}{l}95^{10} \mathrm{~B} \text {-lined tubes } \\
4 \text { banks } \\
70.0 \times 44.8 \times 54.0\end{array}$ & NA & & & & $19.2 \%$ & 115 & 3.2 \\
\hline $\begin{array}{l}\text { GE Reuter- } \\
\text { Stokes } \\
\text { ABUNCL } \\
\text { Passive } \\
\text { BWR }^{\# \# \#} \\
\end{array}$ & $\begin{array}{l}72^{10} \text { B-lined tubes } \\
4 \text { Rectangular banks } \\
78.1 \times 16.5 \times 23.4\end{array}$ & NA & $12.1 \%$ & 65.6 & 2.23 & $13.4 \%$ & 71.4 & 2.5 \\
\hline $\begin{array}{l}* \\
* * \\
* * * \\
* * * \\
\# \\
\# \# \\
\# \# \\
\# \# \#\end{array}$ & $\begin{array}{l}\text { Evaluated from rep } \\
\text { From [Croft et al. } \\
\text { From [Menlove et } \\
\text { Not measured at L } \\
\text { From [Canberra } 20 \\
\text { From [Canberra } 20 \\
\text { From [Canberra 20 } \\
\text { From [McKinny } 20\end{array}$ & $\begin{array}{l}\text { orted } 64 \\
011] \text { usir } \\
\text { 1. 1990] } \\
\mathrm{NL}, \mathrm{Ho} \\
1] \text { for } \mathrm{J} \\
1] \text { for } \mathrm{J} \\
1] \text { for } \mathrm{J} \\
\text { 12] }\end{array}$ & $\begin{array}{l}\text { s optimal ga } \\
{ }^{252} \mathrm{Cf} \text { cente } \\
\text { sing }{ }^{252} \mathrm{Cf} \mathrm{c} \\
\text { ard Menlov } \\
\mathrm{C}-71 \text { using } \\
\mathrm{C}-72 \text { using } \\
\mathrm{C}-73 \text { using }\end{array}$ & $\begin{array}{l}\text { e width } \\
\text { ed in sar } \\
\text { tered in } \\
\text { private } \\
\text { tive me } \\
\text { tive me } \\
\text { tive me }\end{array}$ & $\begin{array}{l}\text { f } 1.257 \text { til } \\
\text { ple cham } \\
\text { sample ch } \\
\text { communic } \\
\text { surement } \\
\text { surement } \\
\text { surement }\end{array}$ & $\begin{array}{l}\text { es tau } \\
\text { nber } \\
\text { ion, July }\end{array}$ & 2012 & \\
\hline
\end{tabular}




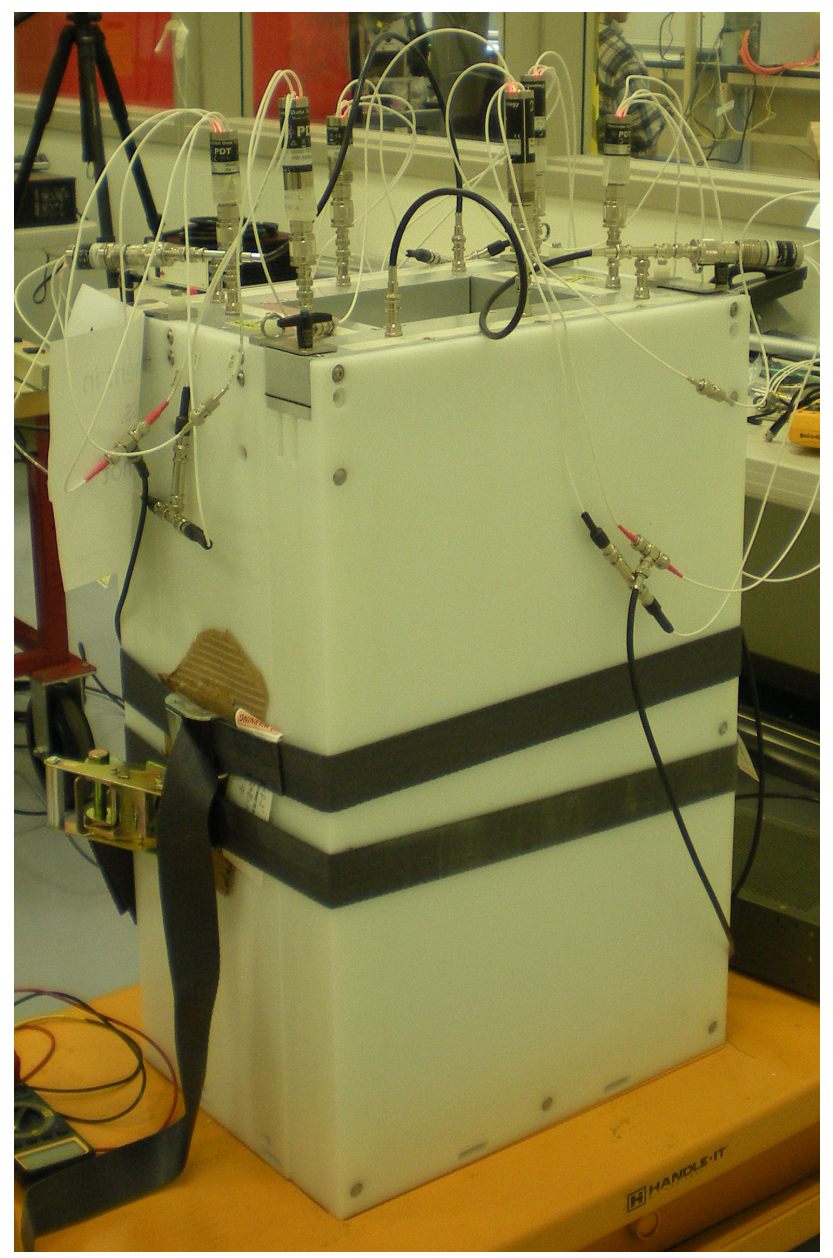

Figure 2.2. GE Reuter Stokes ABUNCL.

Figure 2.3 shows the schematic design of this system as seen from one side. Figure 2.4 shows a horizontal slice through the assembly illustrating the 72 tubes in the moderator. Figure 2.5 shows the wiring diagram of how the detectors are connected in groups of tubes. The tubes in the outer layer of the as built system have a thicker lining than the tubes in the inner layer $\left(0.62 \mathrm{mg} / \mathrm{cm}^{2}\right.$ compared to $0.34 \mathrm{mg} / \mathrm{cm}^{2}$ ). The dual tube lining thickness configuration was determined through modeling by GE Reuter-Stokes to provide better performance than a uniform coating thickness for all the tubes. The composition of the lining is proprietary to GE Reuter-Stokes, so modeling by PNNL will use an approximate lining composition.

Modeling by GE Reuter-Stokes predicted a neutron detection efficiency $(\varepsilon)$ of $13.4 \%$, a die-away time $(\tau)$, which is the average lifetime of a neutron in the counter, of $71.4 \mu \mathrm{s}$ (as determined by the Rossi-Alpha Distribution method), and a Figure-of-Merit $\left(\varepsilon^{2} / \tau\right)$ of 2.5 , using a $150 \mathrm{keV}$ threshold [McKinny 2012]. Measurements by GE Reuter-Stokes gave 12.1\% efficiency and a 65.6 us die-away time, for a Figure-of-Merit (FOM) of 2.23, slightly below the model estimate 
[McKinny 2012]. For comparison, the ${ }^{3} \mathrm{He}-$ based JCC-71 UNCL has a reported efficiency in a passive configuration of $11.5 \%$, a die-away time of $51 \mu \mathrm{s}$, and a FOM of 2.6.

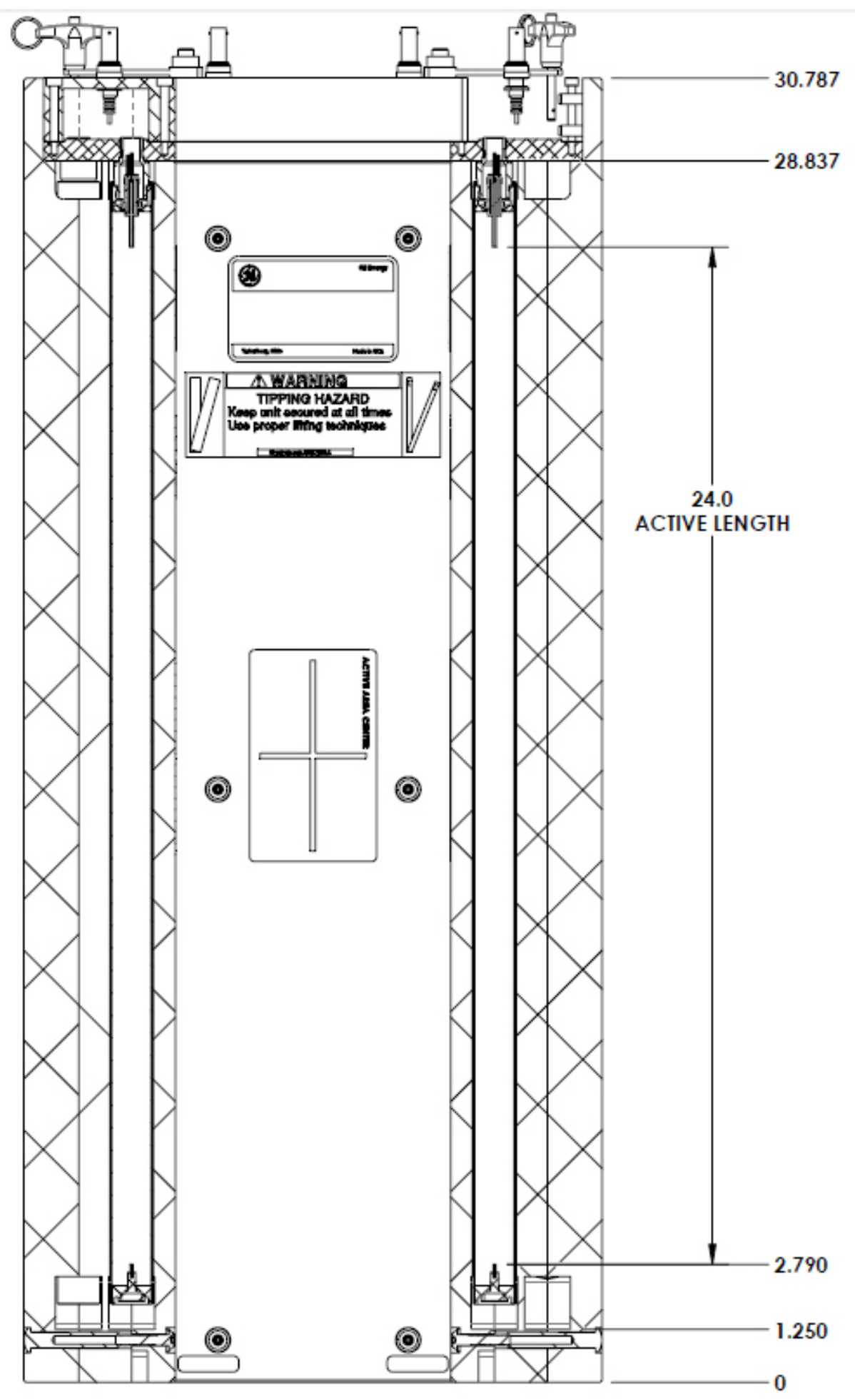

Figure 2.3. GE Reuter Stokes ABUNCL vertical cross-section (dimensions in inches). 


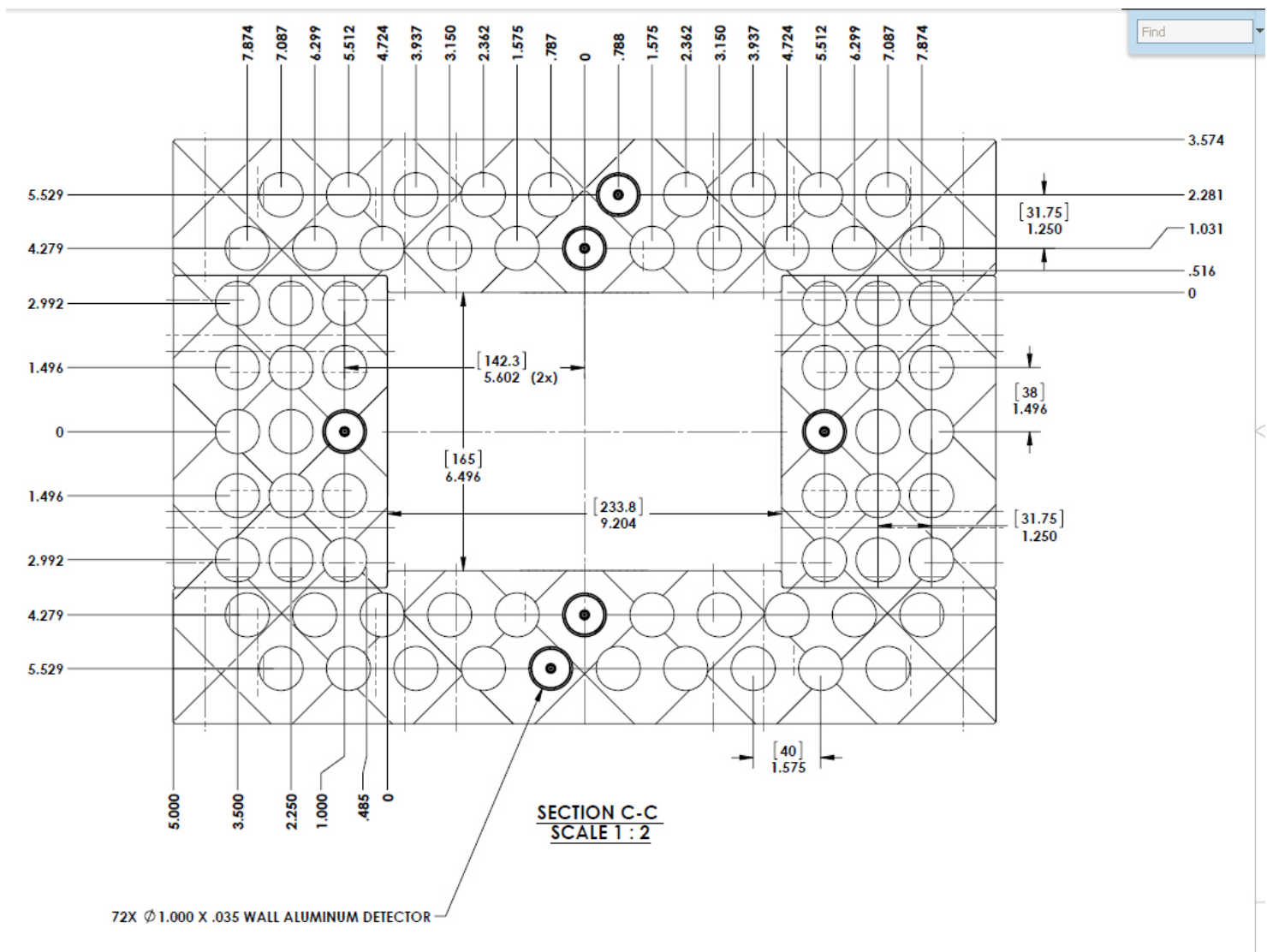

Figure 2.4. GE Reuter Stokes ABUNCL horizontal cross-section (dimensions in inches).

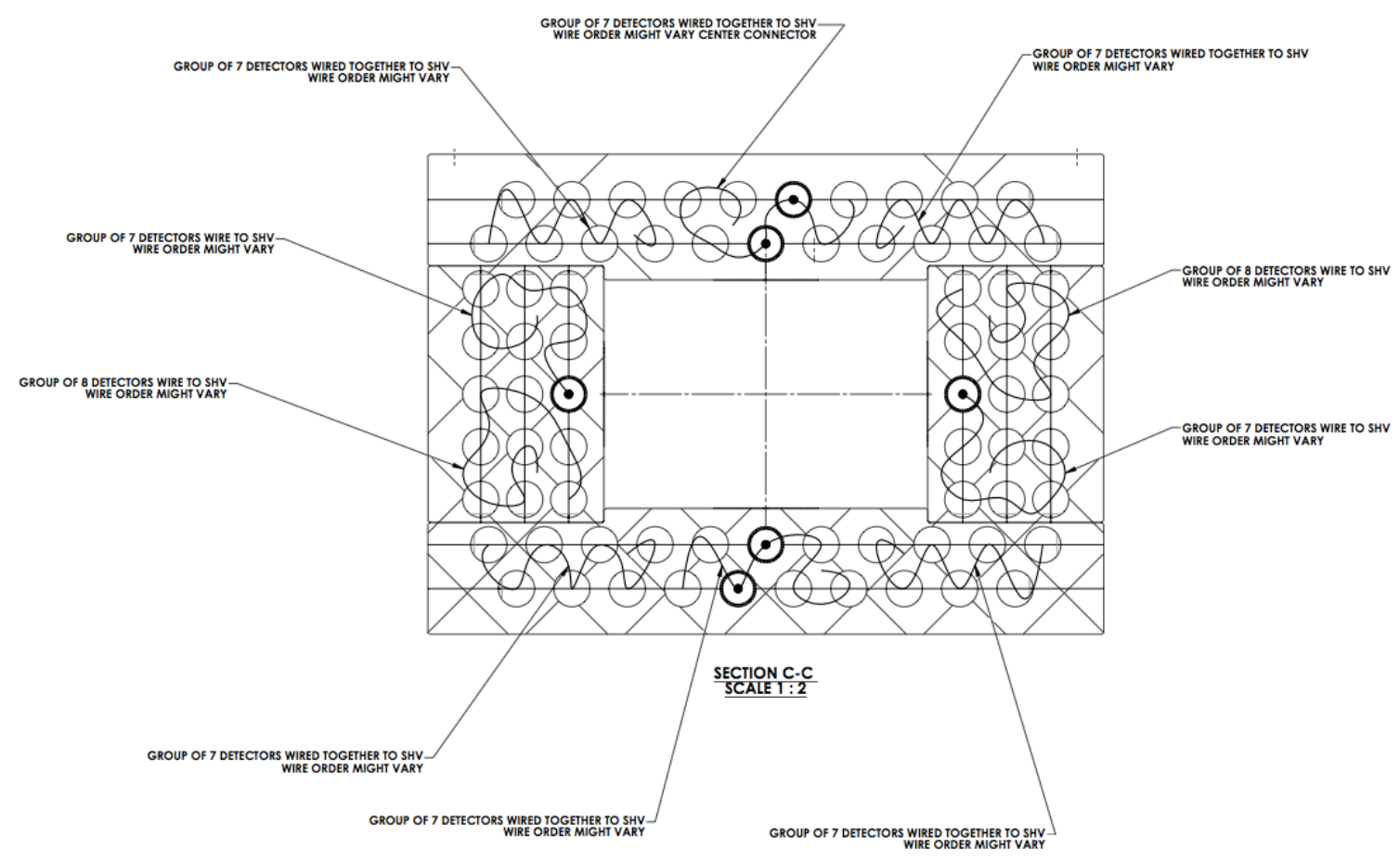

Figure 2.5. GE Reuter Stokes ABUNCL wiring diagram. 


\section{3. ${ }^{10} \mathrm{~B}$-lined ABUNCL Module Testing}

The GE Reuter-Stokes ABUNCL was shipped to PNNL in November 2012, and was assembled in Building 3420, room 1304, as shown in Figure 3.1. Two neutron sources were used. The neutron source used for initial testing (56595-130E) was $1.9 \mu \mathrm{Ci}$ with an uncertainty of $5 \%$ $[8200(400)$ neutrons/s] on the date of use. A more precisely calibrated source was used later, as noted.

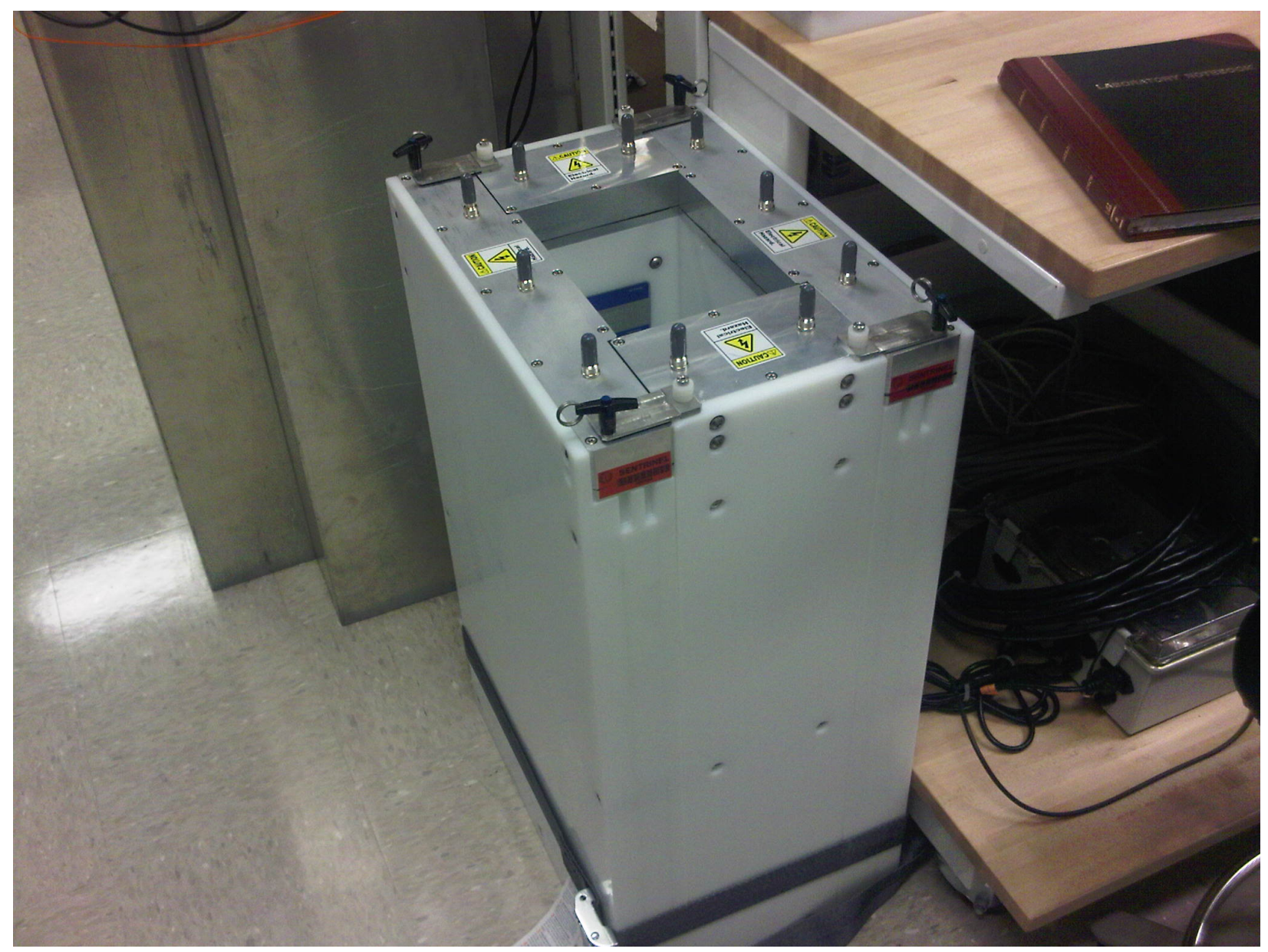

Figure 3.1. GE Reuter Stokes ABUNCL set up at PNNL.

The initial testing reported here for this prototype system was:

- Measure voltage plateaus for each of the ten sections of the detector.

- Assemble complete electronics for all channels and adjust thresholds.

- Initial measurement of assembly efficiency.

- Initial measurement of assembly die-away-time.

- Measurement of assembly uniformity.

- Repeat measurements of efficiency and die-away-time with a calibrated source. 
Future measurements will be made for an active configuration of this system, followed by measurement with nuclear fuel.

\section{Voltage Plateau Measurements}

There are four sections to the detector assembly, each with either two or three groups of detectors. Voltage plateau measurements were performed on each of the ten detector groups of the ABUNCL on November 12-15, 2012. An Ortec 142A preamp and nuclear instrumentation module (NIM) electronics were used for these measurements. Figure 3.2 shows the plateau measurement for the three groups (right, middle and left) in Section 1 of the ABUNCL, while Figure 3.3 shows it for the two groups (right and left) in Section 2. The lines are trend lines to guide the eye.

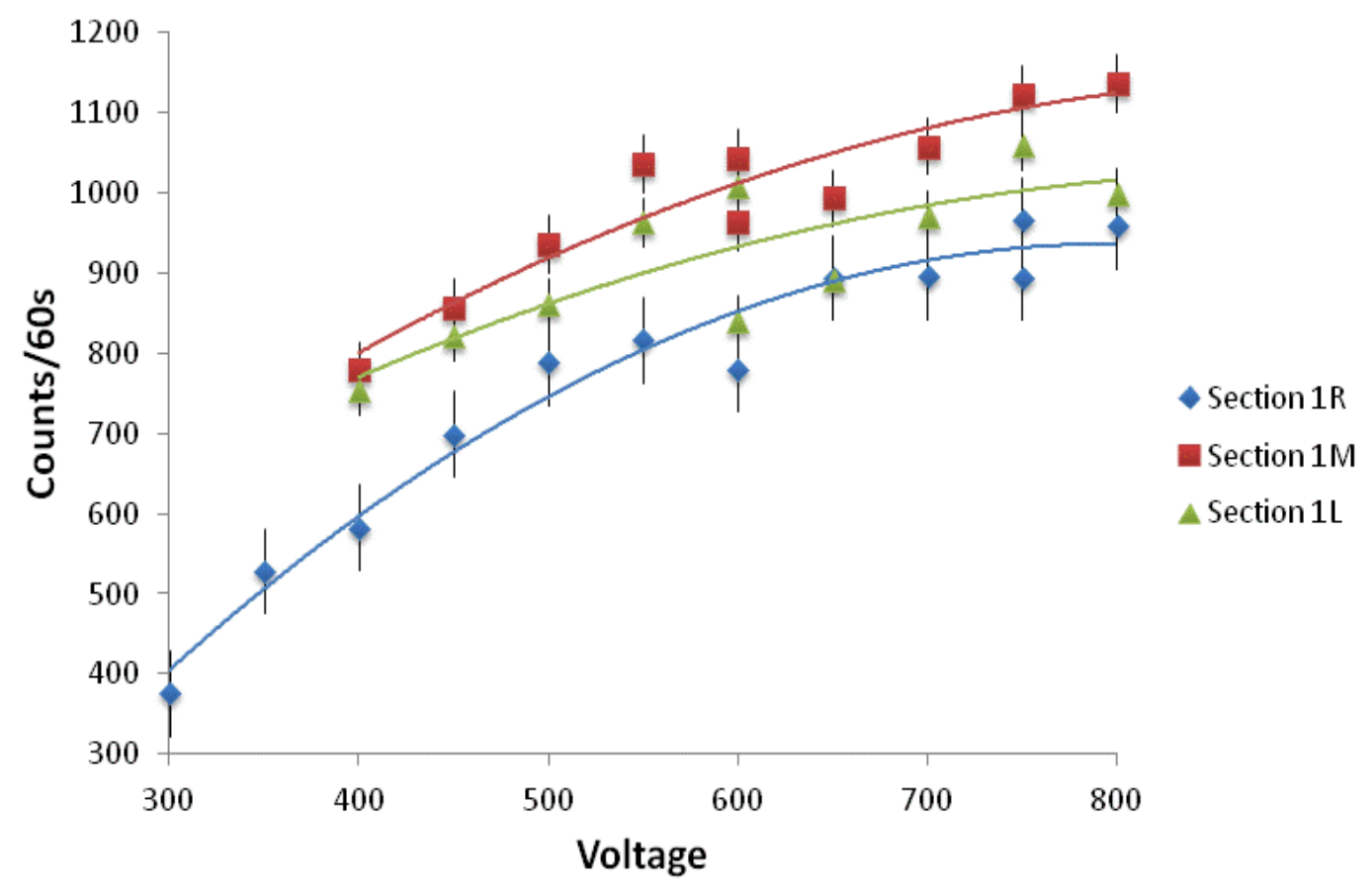

Figure 3.2. Voltage plateau measurements for the three detector groups (right, middle, left) in Section 1. 


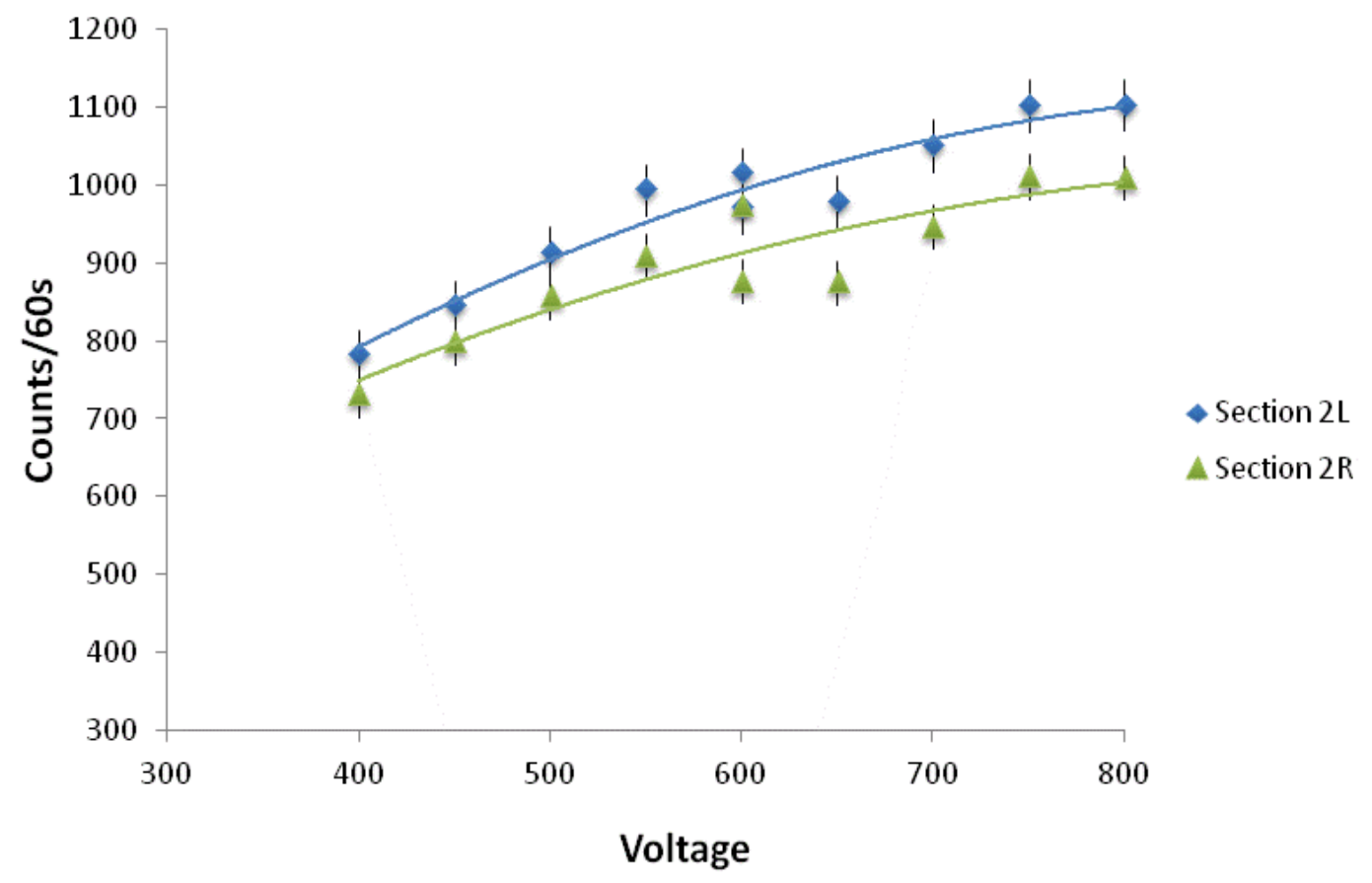

Figure 3.3. Voltage plateau measurements for the two detector groups (left and right) in Section 2.

Measurements were made with two different amplifier gain settings that were changed at $600 \mathrm{~V}$, accounting for the discontinuity in the data observed at that voltage for some of the sections.

Figure 3.4 shows the plateau measurement for the groups (left, middle and right) in Section 3 and Figure 3.5 shows it for the groups (left and right) in Section 4 of the ABUNCL.

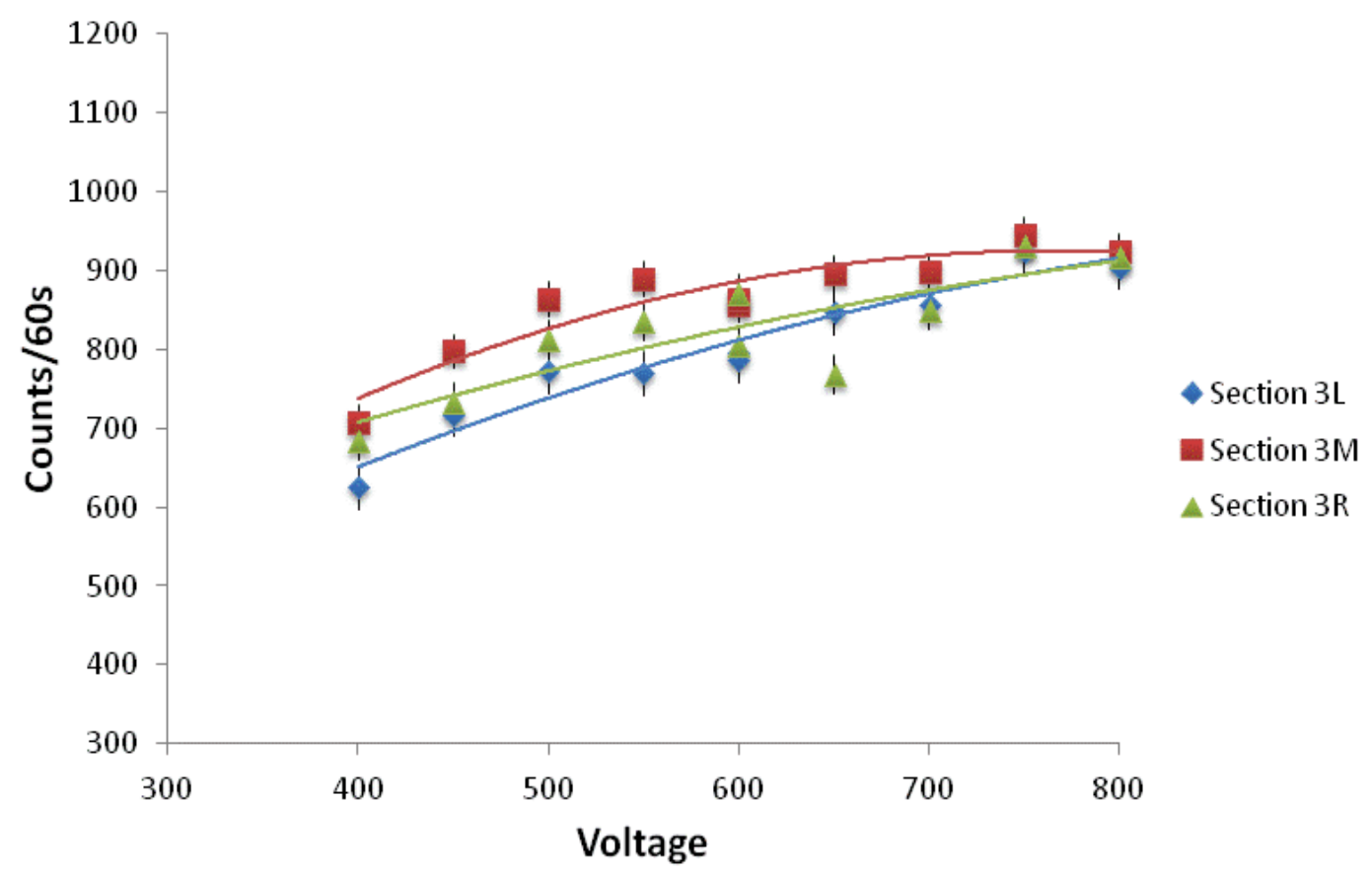

Figure 3.4. Voltage plateau measurements for the three detector groups (left, middle, right) in Section 3. 


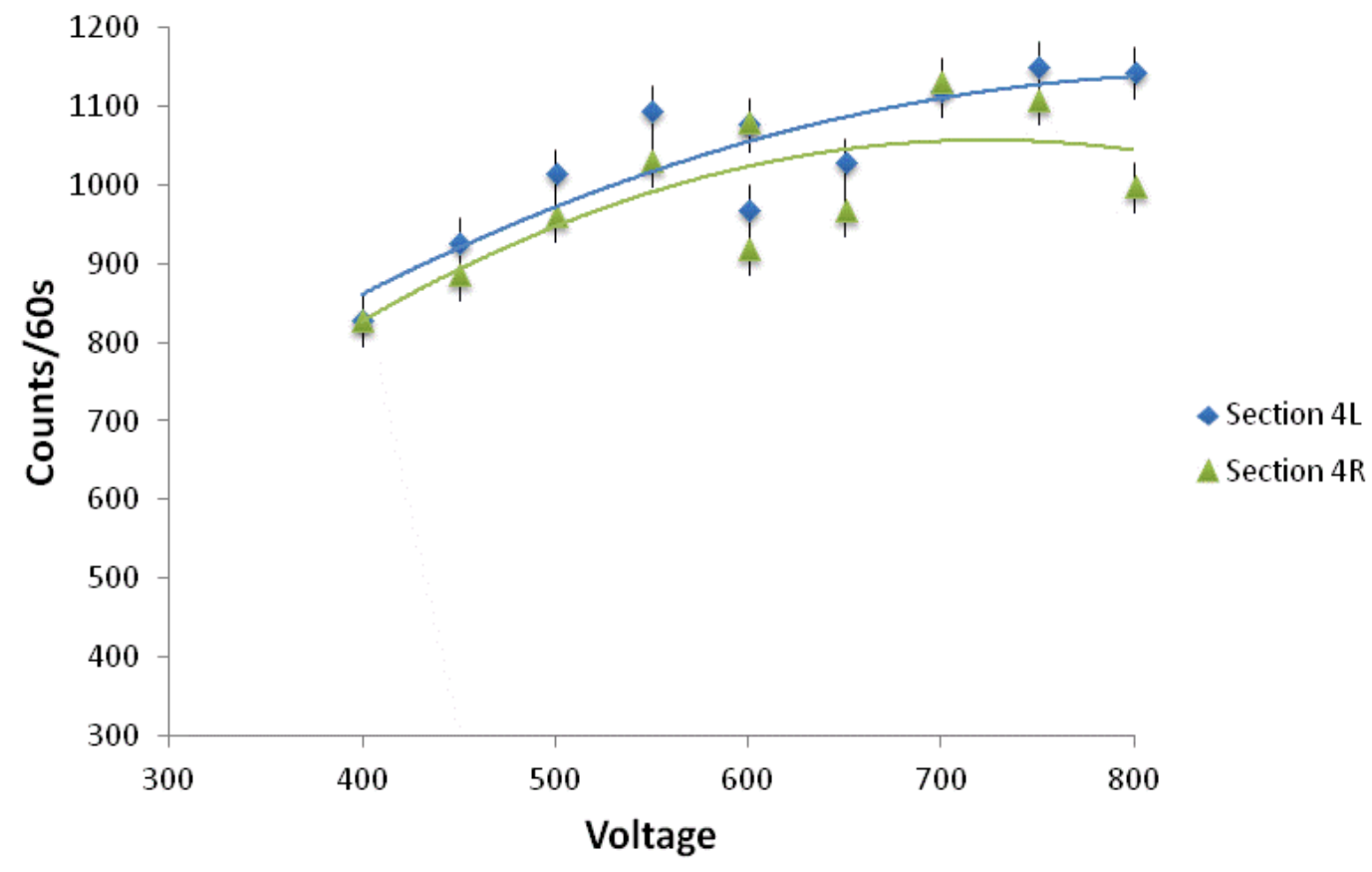

Figure 3.5. Voltage plateau measurements for the two detector groups (left and right) Section 4.

All four plots show the net data with a fixed threshold at channel 10 (out of 1024 channels). The measurements indicate that an operating potential of 700-800 V is reasonable for all of the detector groups. A $750 \mathrm{~V}$ potential was eventually used for all final results reported here. Figure 3.6 shows a photograph of the detector system during the plateau measurement on the right group in Section 3. The neutron source was contained in the polyethylene cylinder only for these measurements since it did not affect the results. 


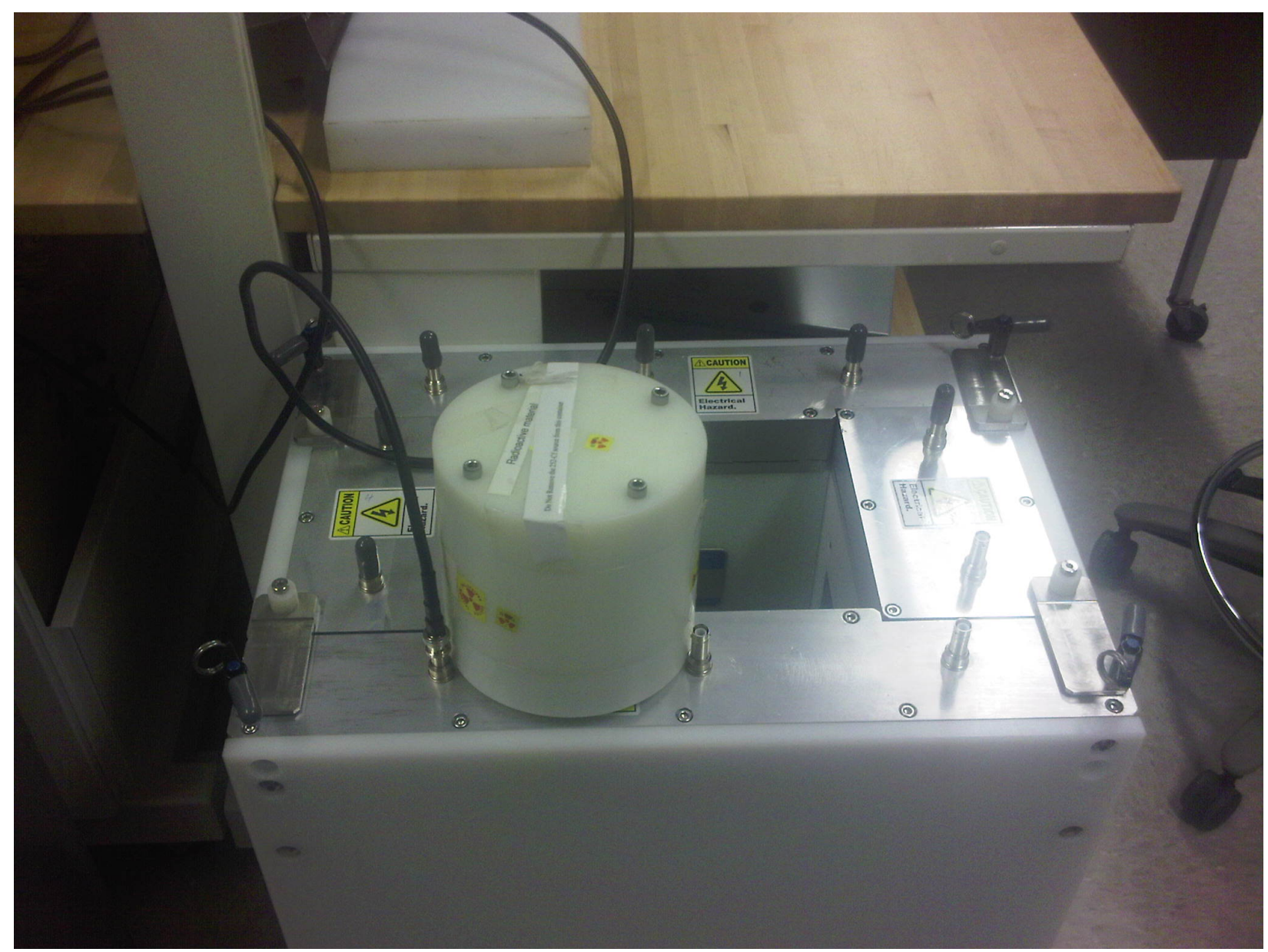

Figure 3.6. Source used for performing voltage plateau measurements.

\section{PDT Preamp Measurements}

Preamps were procured from Precision Data Technology (Everett, WA) for the ABUNCL. Since there are ten electrical connections to the multiple tubes in each of the four modules, four model PDT20A-SHV:P-12V-B10 preamps, one for each module, with the capability of generating high voltage, along with six model PDT10A-SHV:P-12V-B10 preamps, were procured. Two preamps are seen connected in Figure 3.7, with the PDT20A model on the left. One of the preamps had to be returned to the manufacturer for repair since it did not provide an energy output signal. 


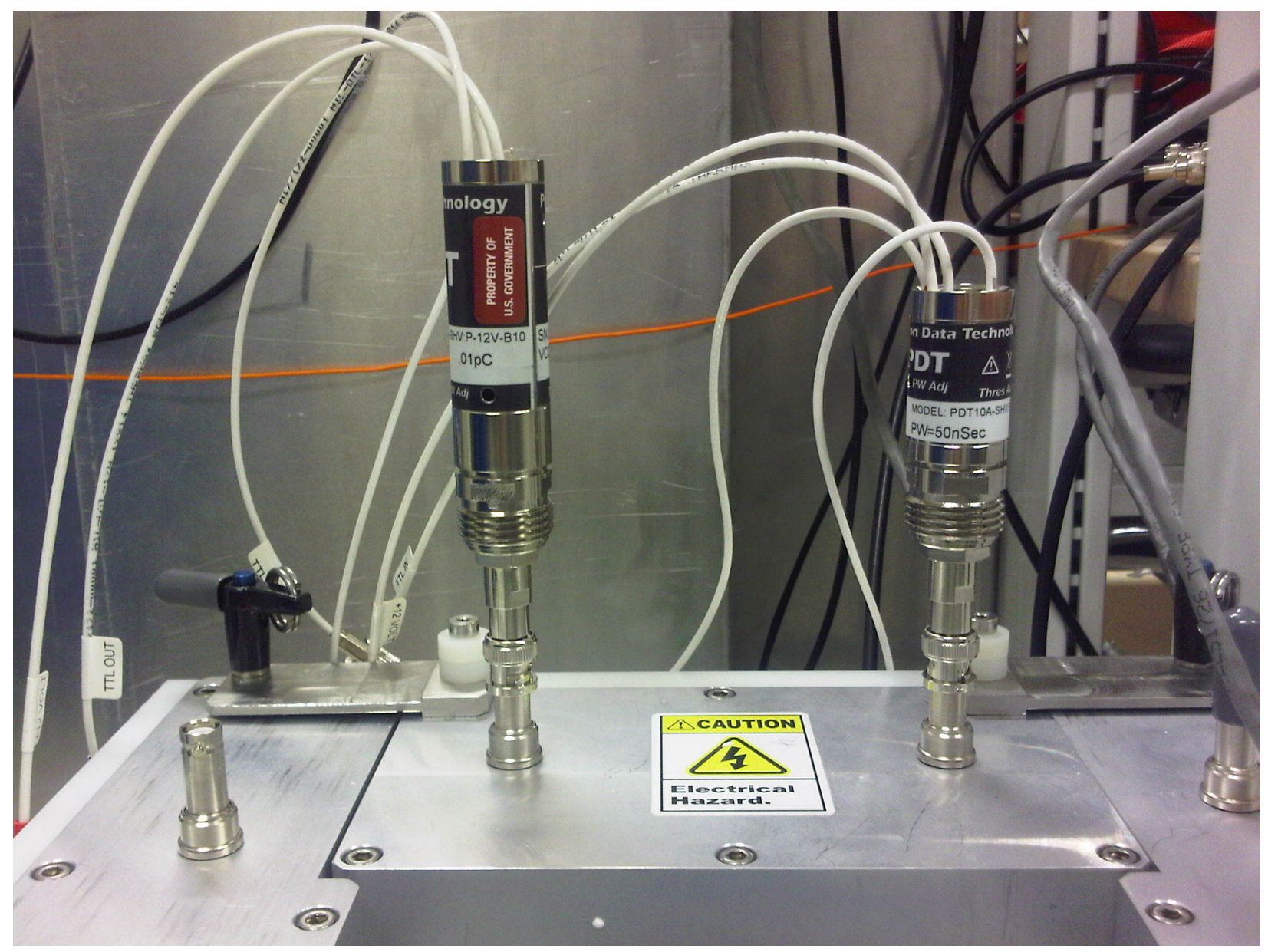

Figure 3.7. Preamps in place on one module.

The PDT20A preamps provided high voltage to the other preamp(s) on each module. All preamps are powered from a NIM bin $+12 \mathrm{~V}$ power supply daisy chain. The transistor-transistor logic (TTL) digital outputs from the preamps were daisy chained together and fed into an Ortec AMSR 150 shift register (Oak Ridge, TN), or alternately to a NIM module to generate a gate for obtaining an energy spectrum. Energy spectra were obtained from the monitor output of each preamp using an Amptek Pocket MCA (Bedford, MA) connected to a laptop computer. The complete set up is seen in Figure 3.8. 


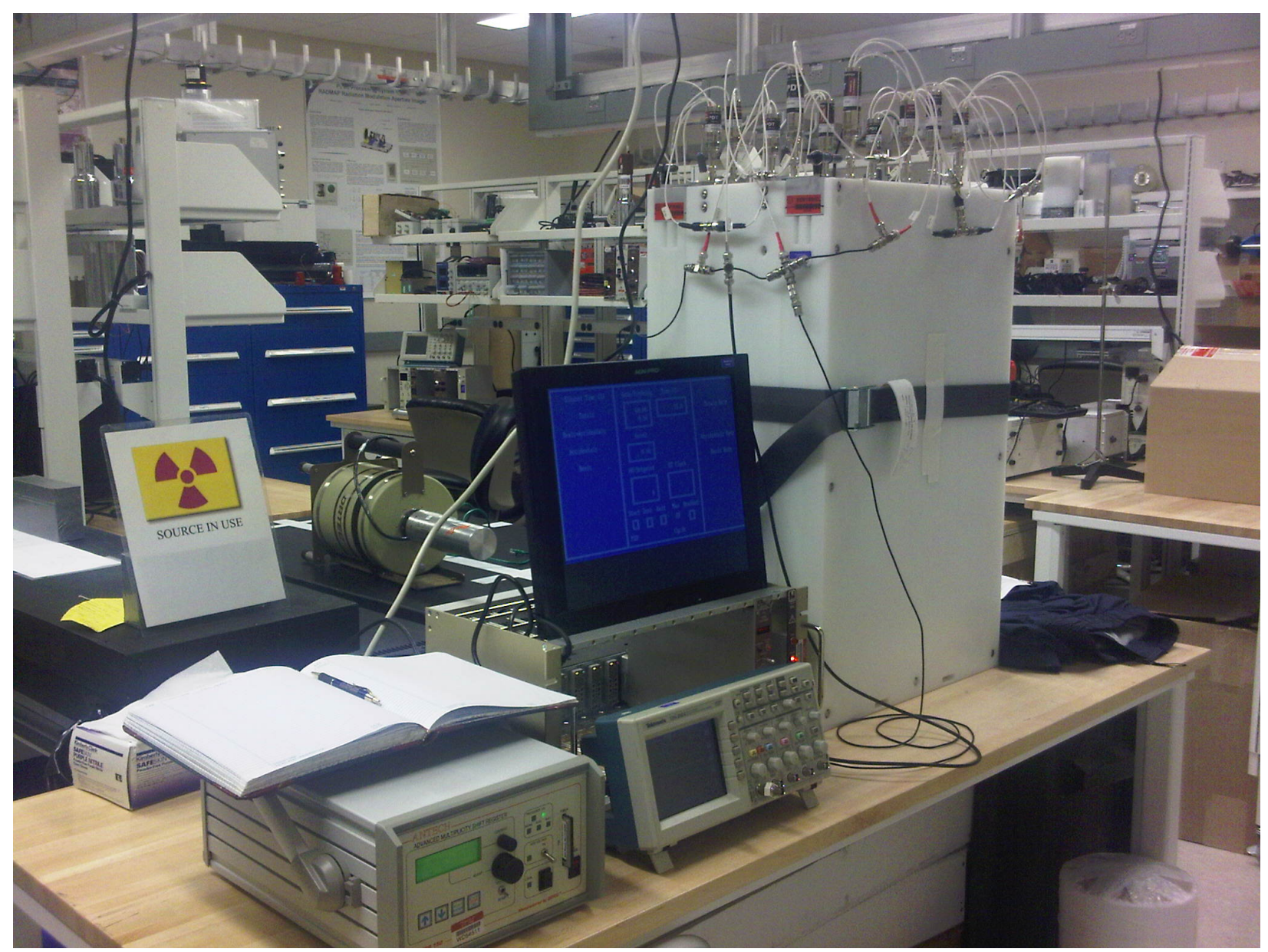

Figure 3.8. ABUNCL test set up.

Since GE Reuter Stokes used a $150 \mathrm{keV}$ threshold for their testing, this same threshold was chosen for testing at PNNL. The threshold is set in the preamp through a combination of tube voltage, preamp gain, and a threshold adjustment on December 3, 2012. After some trial measurements, the tube voltage was set to $750 \mathrm{~V}$, and each preamp gain was adjusted to place the $1.47 \mathrm{MeV}$ edge of the spectrum at channel 700, with the threshold at channel 70. Figure 3.9 shows a 120-s sample boron-lined tube energy spectrum from module 3-middle. It can be seen that the lower threshold is not a hard cutoff, and thus affects the ability to set a precise threshold energy. 


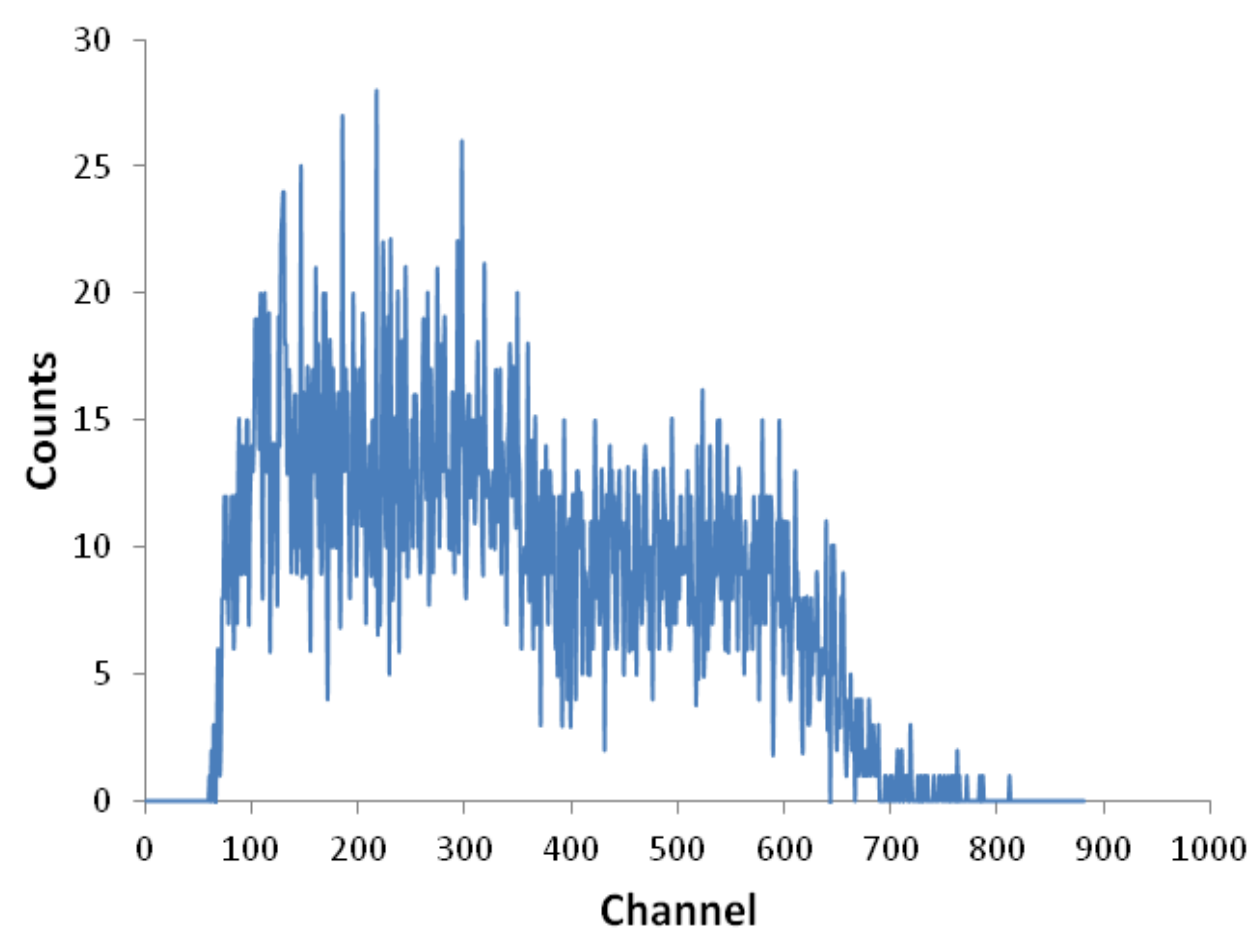

Figure 3.9. Energy spectrum from section $3 M$ gated on threshold.

\section{Uniformity Measurements}

The $1.9 \mu \mathrm{Ci}{ }^{252} \mathrm{Cf}$ source (56595-130E) was used to make measurements of the efficiency and uniformity of the ABUNCL on December 17, 2012. Later measurements of efficiency were made with another more precisely characterized neutron source.

Measurements were made in the volume of the ABUNCL at three heights. These were at the bottom, the midpoint $(38 \mathrm{~cm})$, and the top $(76 \mathrm{~cm})$. Five spatial locations were measured: the four corners between segments, and the vertical centerline. The average efficiency in the four corners was $6.1 \%$ at the bottom, $14.3 \%$ at the midpoint, and 3.0\% at the top. The results were very consistent at each height, varying by less than $\pm 0.1 \%$ between the four corners. The centerline measurements produced efficiencies of $6 \%, 13 \%$, and $3 \%$ at the bottom, middle, and top, respectively.

Additional measurements were made of the efficiency as a function of height in one corner (between modules 1 and 4) and on the vertical centerline, as shown in Figure 3.10. The statistical uncertainty is smaller than the symbols in the plot. The maximum efficiency in the center is slightly below that in the corner. The efficiency approximately follows a second order polynomial in shape. The region of relatively uniform efficiency extends about $10 \mathrm{~cm}$ in the center. 


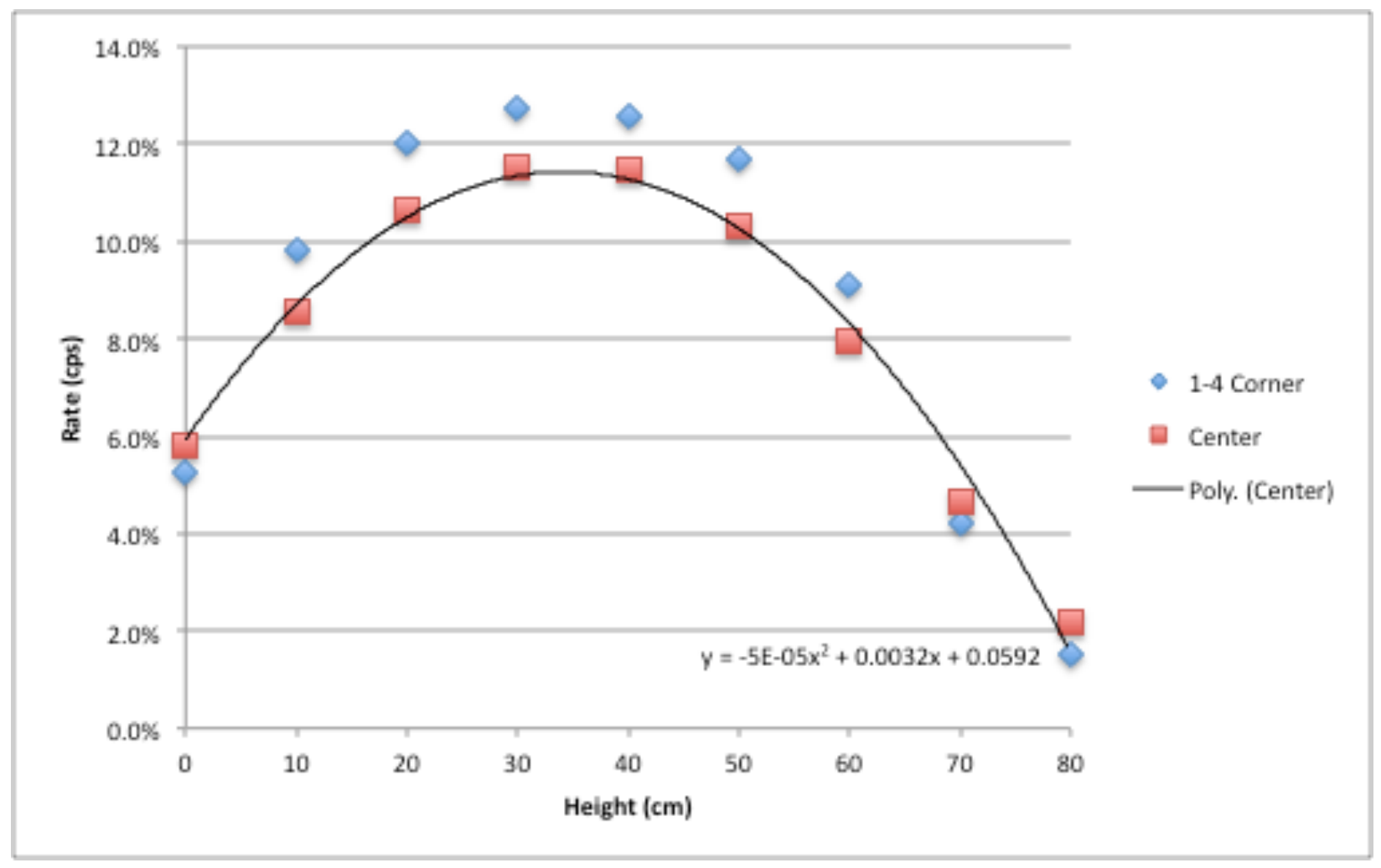

Figure 3.10. Efficiency as a function of height.

\section{Efficiency Measurement}

The same ${ }^{252} \mathrm{Cf}$ source (56595-130E) placed in the center of the detector was used to perform shift register measurements of the ABUNCL with various gate widths from $20 \mu$ s to $200 \mu \mathrm{s}$, in $10 \mu$ s steps (on December 10, 2012). The total neutron trigger rate, or singles rate, was found to be constant over this range at 950(20) counts per second (cps) using a 60-s measurement period, where the uncertainty is between the multiple measurements. This corresponds to an efficiency of $11.6(6) \%$ where the uncertainty is dominated by the source uncertainty, compared to a value of $12.1 \%$ measured by GE Reuter Stokes.

A NIST calibrated neutron source (60208-44) with an activity of $9.44 \mu \mathrm{Ci}$, or $4.08(7) \times 10^{4}$ neutrons/s, on the date of measurement (December 17, 2012) was used to make a more precise measurement of the ABUNCL efficiency. A 500-s acquisition time was used. The result was an efficiency of $11.6(3) \%$ measured in the center of the system.

\section{Die-Away Time Measurements}

Three methods were used to determine the die-away time for the ABUNCL (on December 10-13, 2012): the double gate ratio method, the pre-delay variation method, and the gate variation method. 


\section{Double Gate Ratio Method}

The first method utilized the relationship:

$$
\mathrm{R} \sim \mathrm{e}^{-\mathrm{p} / \tau}\left(1-\mathrm{e}^{-\mathrm{G} / \tau}\right)
$$

Equation 3.1

where $\mathrm{R}$ is the real time-correlated coincident neutron detection rate, or the reals rate, $\mathrm{p}$ is the pre-delay length and $\mathrm{G}$ is the gate length. Taking the ratio of two reals rate measurements for gate lengths $\mathrm{G}_{2}=2 \mathrm{G}_{1}$ and solving for $\tau$ gives:

$$
\tau=-\mathrm{G}_{1} / \ln \left(\mathrm{R}_{2} / \mathrm{R}_{1}-1\right)
$$

Equation 3.2

Measurements taken for $500 \mathrm{~s}$ with a pre-delay of $4 \mu \mathrm{s}$ and varying gate lengths are shown in Table 3.1. The total rate is the neutron trigger rate, and the accidentals rate at which non-timecorrelated neutrons are detected as coincident pairs. All rates are in cps. The Die-Away Time column is derived from Equation 3.2 using gate pairs, with $\mathrm{G}_{1}$ being the smaller of the gate lengths (e.g., $50 \mu \mathrm{s}$ with $100 \mu \mathrm{s}$ ). The average die-away time derived form this method was 75(3) $\mu \mathrm{s}$. An analysis of similar data taken for only $60 \mathrm{~s}$ with a pre-delay of $4.5 \mu$ s gave an average dieaway time of 83(14) $\mu$ s.

Table 3.1. Data for die-away time measurement.

\begin{tabular}{|r|r|r|r|r|}
\hline Gate $(\boldsymbol{\mu} \mathbf{s})$ & Total Rate & Accidentals Rate & Reals Rate & $\begin{array}{c}\text { Pair-Computed } \\
\text { Die-Away Time } \\
(\boldsymbol{\mu} \mathbf{s})\end{array}$ \\
\hline 50 & 927 & 42.99 & 67.06 & $71.9[$ for $50 / 100]$ \\
\hline 60 & 931 & 52.03 & 75.28 & $72.7[$ for $60 / 120]$ \\
\hline 70 & 928 & 60.25 & 82.7 & $73.8[$ for $70 / 140]$ \\
\hline 80 & 928 & 68.96 & 88.31 & $78.1[$ for $80 / 160]$ \\
\hline 100 & 928 & 86.09 & 100.53 & \\
\hline 120 & 927 & 103.16 & 108.26 & \\
\hline 140 & 926 & 120.09 & 114.75 & \\
\hline 160 & 925 & 136.81 & 120 & \\
\hline
\end{tabular}

\section{Pre-Delay Method}

The pre-delay method fits Equation 3.1 to data where $\mathrm{p}$ is varied while $\mathrm{G}$ is held constant. For these measurements, the gate width was held constant at $50 \mu$ s. The AMSR 150 only supports pre-delay values up to $7.5 \mu \mathrm{s}$, which limits the capability of this approach. Figure 3.11 shows the result for this measurement and a trend line fit. The result for the die-away time from this method was $67(1) \mu \mathrm{s}$. However, the measurement spans only $\sim 10 \%$ of the implied die-away time and thus little confidence is attribute to this value. 


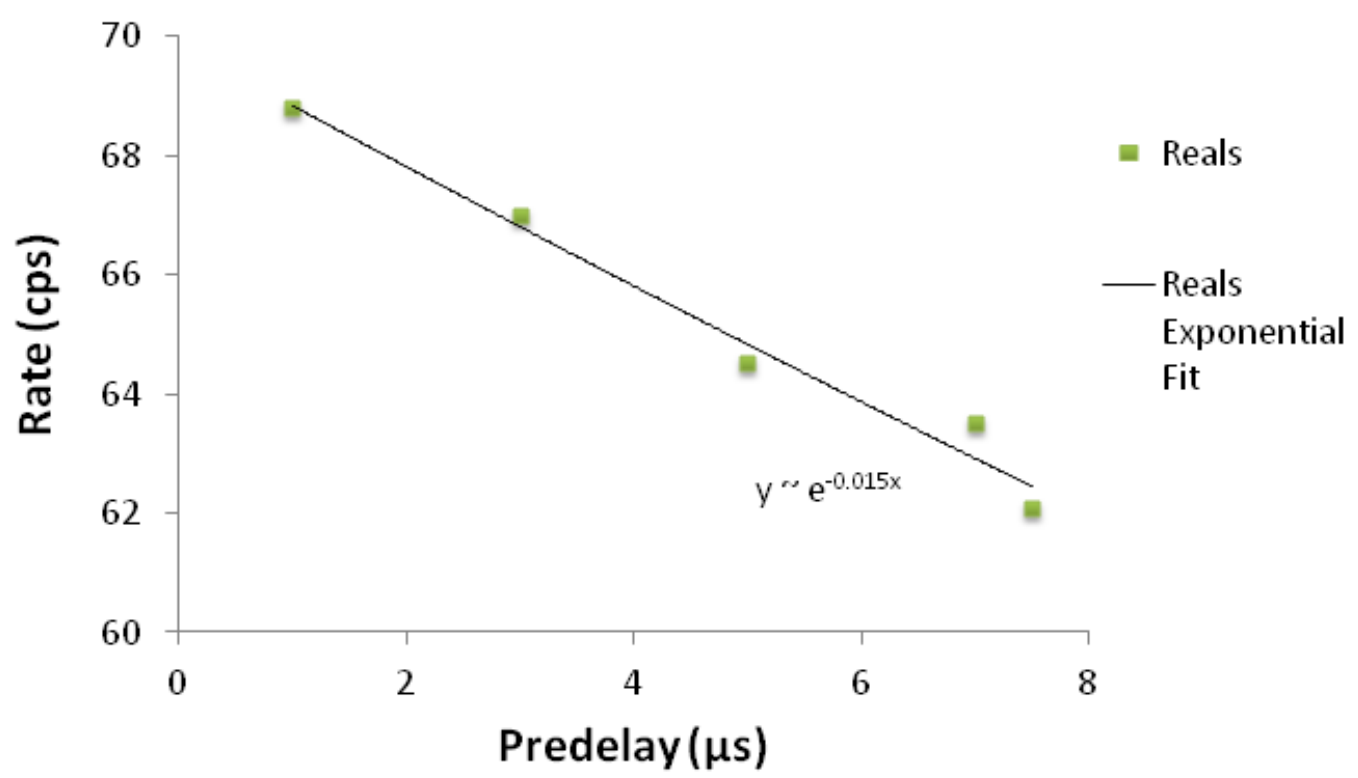

Figure 3.11. Dependence of real and accidental rates on gate width.

\section{Gate Variation Method}

The gate variation method fits measured reals-rate data to the exponential function of Equation 3.1 with the pre-delay constant while varying the gate width. Two sets of data were obtained using different parameters. Figure 3.12 shows the fits for both sets of data, where total uncertainties are shown.

The first set of data had a fixed pre-delay value of $4.5 \mu \mathrm{s}$ and a measurement time for each point of $60 \mathrm{~s}$, with gate widths from $20 \mu \mathrm{s}$ to $200 \mu \mathrm{s}$. The fit to this data provided a value for the dieaway-time of 78.8(2) us. The accidental rate was found to be linearly dependent on the gate width, as expected.

The second set of data (listed in Table 3.1) was taken with a pre-delay of $4 \mu \mathrm{s}$, a measurement time of $500 \mathrm{~s}$, and gate widths from $50 \mu \mathrm{s}$ to $160 \mu \mathrm{s}$. The fit to this data provided a value for the die-away-time of 73.4(1) $\mu \mathrm{s}$. Averaging the two results gives a value of 75.2(1) $\mu \mathrm{s}$.

\section{Die-Away Time and Optimal Gate Width Conclusions}

The fit to the gate variation data is perhaps the most accurate of the methods measured since it fits a larger data set, giving 75.2(1) $\mu$ s for the die-away time as compared to 67(1) $\mu$ s for the predelay method and 75(3) $\mu$ s for the ratio method. The gate variation method data spans up to twice the derived die-away time and thus is perhaps a more robust method for obtaining a true die-away time. Because the die-away time is such an important parameter, further work will be performed to understand the difference in values derived from different approaches. A more consistent result might be obtained for the pre-delay method if the pre-delay time could be increased while keeping the gate width fixed. This approach will be pursued. At this time, the value of 75.2(1) $\mu \mathrm{s}$ will be used for further work on this system. This value for the die-away time 
implies that the optimal gate width, derived by multiplying 1.26 times the die-away time, is 95 $\mu \mathrm{s}$.

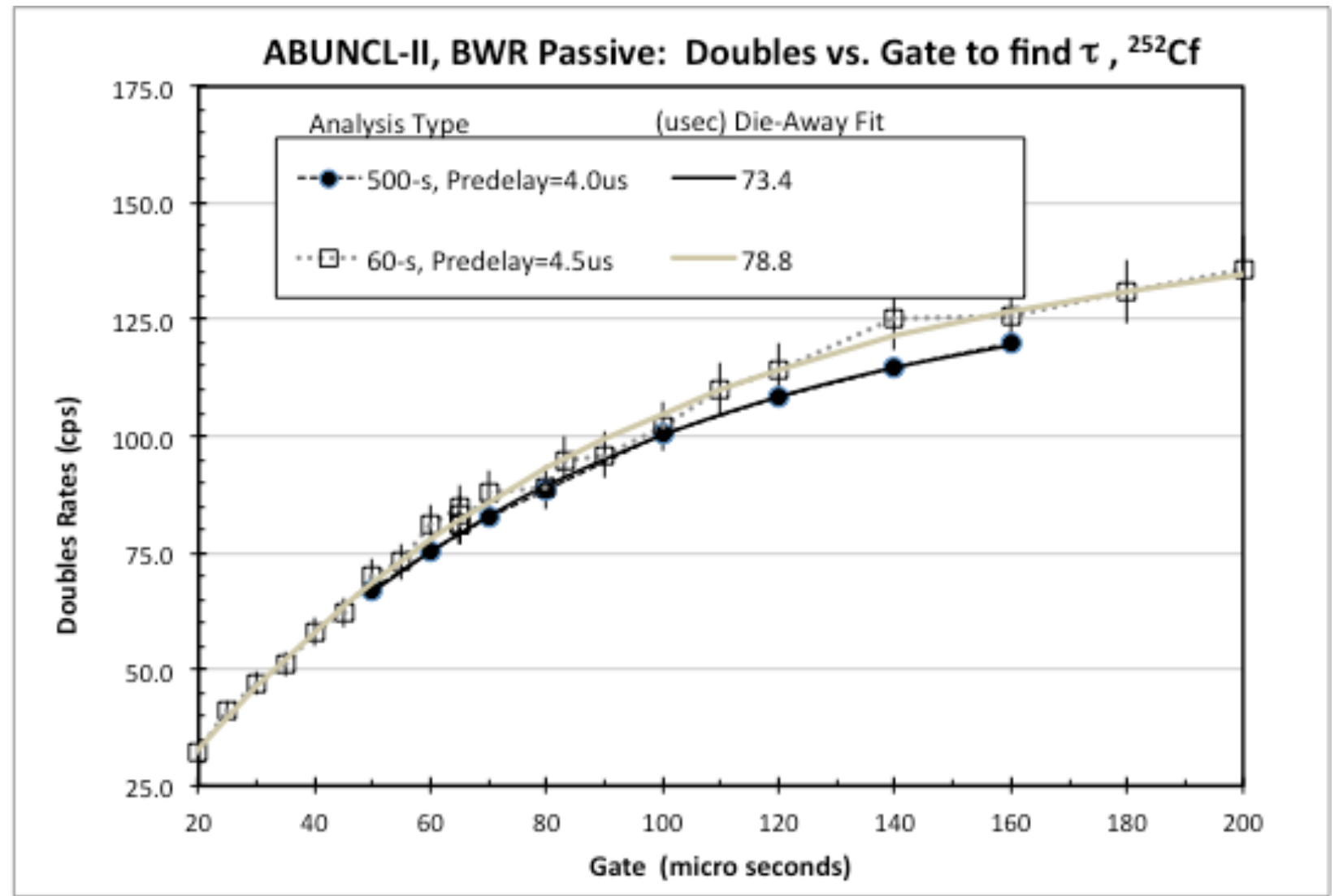

Figure 3.12. Dependence of reals (doubles) rates on gate width. 


\section{4. ${ }^{10}$ B-lined ABUNCL Modeling Plan}

Previous work at PNNL modeled the eight configurations of the ${ }^{3} \mathrm{He}$-based UNCL coincidence counter [Siciliano 2012b]. Various designs of an ABUNCL using boron-lined tubes were also modeled [Rogers 2012b].

The MCNP model developed by GE Reuter-Stokes was provided to PNNL under a nondisclosure agreement. The model provided had the information about the boron lining composition removed, so modeling will need to be performed with various lining compositions in order to match the results from GE Reuter-Stokes.

The MCNP model for the ABUNCL will be run and some variations will be made, in particular, a model of the active ABUNCL will be developed. This will include a HDPE block to replace one of the small sides of the ABUNCL to hold the AmLi neuron source to be used for active measurements. Other modifications such as adding more HDPE or Cd to the outside of the ABUNCL may be modeled.

Once validated with the neutron source measurements, a model for measurements of nuclear fuel modules may need to be developed if time allows. 


\section{Conclusions}

This report discussed the characterization of a full-scale boron-based ABUNCL coincidence counter developed by GE Reuter-Stokes for applications in safeguards for Task 2 of the project Coincidence Counting With Boron-Based Alternative Neutron Detection Technology.

The efficiency, die-away time, and optimal gate length were determined by laboratory measurements. The efficiency determined from a measurement of a centered ${ }^{252} \mathrm{Cf}$ source was found to be $11.6(3) \%$. This is compared to a value reported by GE Reuter-Stokes of $12.1 \%$ [McKinny 2012]. The die-away time was found to be 75.2(1) $\mu$ s, giving an optimal gate width of $95 \mu \mathrm{s}$. This die-away time is compared to a value reported by GE Reuter-Stokes of $65.6 \mu \mathrm{s}$ [McKinny 2012]. Further investigations of die-away time will be performed.

Combining the efficiency and die-away time gives a FOM $\left(\varepsilon^{2} / \tau\right)$ of 1.8 , compared to the number reported by GE Reuter-Stokes of 2.23 [McKinny 2012]. Table 5.1 shows a comparison of the ${ }^{3} \mathrm{He}$ based passive BWR UNCL-I and BWR UNCL-II to the results for the GE Reuter-Stokes ABUNCL. The GE Reuter-Stokes design was targeting the UNCL-I performance. Future measurements with nuclear fuel will show the capability of this design for safeguards measurements.

Table 5.1. Characteristics of the UNCL and ABUNCL configurations.

\begin{tabular}{|c|c|c|c|c|c|c|c|c|}
\hline \multirow{3}{*}{ Detector } & \multirow{3}{*}{$\begin{array}{c}\text { Total \# Tubes, } \\
\text { Configuration, \& } \\
\text { Fuel Cavity } \\
\text { H x L x W (cm) }\end{array}$} & \multirow{3}{*}{$\begin{array}{l}\text { Total } \\
\text { No. } \\
\text { Moles }\end{array}$} & \multicolumn{6}{|c|}{ Efficiency $(\varepsilon)$, Die-Away Time $(\tau) \&$ FOM $=\varepsilon^{2} / \tau$} \\
\hline & & & \multicolumn{3}{|c|}{ Measurement Results } & \multicolumn{3}{|c|}{ Model Results } \\
\hline & & & $\varepsilon$ & $\tau(\mu s)$ & $\begin{array}{c}\text { FOM } \\
(\%)^{2} / \mu \mathrm{S} \\
\end{array}$ & $\varepsilon$ & $\tau(\mu s)$ & $\begin{array}{c}\text { FOM } \\
(\%)^{2} / \mu \mathrm{s}\end{array}$ \\
\hline $\begin{array}{l}\text { UNCL-I } \\
\text { Passive } \\
\text { BWR }\end{array}$ & $\begin{array}{l}24{ }^{3} \mathrm{He} \text { tubes } \\
4 \text { Rectangular banks } \\
41.4 \times 16.5 \times 23.4\end{array}$ & 0.59 & & & & $16.3 \%$ & 51 & 5.2 \\
\hline $\begin{array}{l}\text { UNCL-II } \\
\text { Passive } \\
\text { BWR } \\
\end{array}$ & $\begin{array}{l}20{ }^{3} \mathrm{He} \text { tubes } \\
4 \text { Rectangular banks } \\
41.3 \times 16.5 \times 16.5 \\
\end{array}$ & 0.49 & & & & $19.1 \%$ & 54 & 6.8 \\
\hline $\begin{array}{l}\text { GE Reuter- } \\
\text { Stokes } \\
\text { ABUNCL } \\
\text { Passive } \\
\text { BWR } \\
\end{array}$ & $\begin{array}{l}72{ }^{10} \mathrm{~B} \text {-lined tubes } \\
4 \text { Rectangular banks } \\
78.1 \times 16.5 \times 23.4\end{array}$ & NA & $\begin{array}{l}12.1 \%{ }^{\# \#} \\
11.6 \%{ }^{\# \#}\end{array}$ & $\begin{array}{l}65.6^{\# \#} \\
75.2^{\# \# \#}\end{array}$ & $\begin{array}{l}2.23^{\# \#} \\
1.8^{\# \# \#}\end{array}$ & $13.4 \%{ }^{\# \#}$ & $71.4^{\# \#}$ & $2.5^{\# \#}$ \\
\hline \#\# & $\begin{array}{l}\text { From [Rogers } 20 \\
\text { From [McKinny } \\
\text { This work }\end{array}$ & $\begin{array}{l}b] \\
12]\end{array}$ & & & & & & \\
\hline
\end{tabular}

The results reported here lay the foundation for the modeling comparison of the current configuration that has just begun, and the development of an active variation of this detector. For the active configuration, one of the four sections of the ABUNCL will be replaced with a highdensity polyethylene block that will hold the AmLi source. This new configuration will be modeled. Measurements of the system performance will be conducted with sources. A transport and lifting system will be developed for the assembly. Testing with nuclear fuel will be conducted after all these activities are complete. 


\section{Acknowledgements}

The United States Department of Energy Office of Nuclear Safeguards and Security (NA-241) supported this work. Pacific Northwest National Laboratory is operated for the United States Department of Energy under contract DE-AC05-76RLO 1830. Azaree Lintereur is a post Masters Research Assistant supported at Pacific Northwest National Laboratory by the Next Generation Safeguards Initiative, Office of Nuclear Safeguards and Security, National Nuclear Security Administration. 


\section{References}

Croft S, A Favalli, MT Swinhoe, CD Rael. 2011. State Of The Art Monte Carlo Modeling Of Active Collar Measurements And Comparison With Experiment. Los Alamos National Laboratory. INMM Conference Record 2011.

Canberra. 2011. Model JCC-71, 72 and 73 Neutron Coincidence Collars. Accessed at www.canberra.com.

Kouzes RT, JH Ely, LE Erikson, WJ Kernan, AT Lintereur, ER Siciliano, DL Stephens, DC Stromswold, RM Van Ginhoven, and ML Woodring. 2010. "Neutron detection alternatives for ${ }^{3}$ He homeland security." Nuclear Instruments and Methods in Physics Research A, 623(3):10351045.

Kouzes RT, JH Ely, AT Lintereur, and ER Siciliano. 2012. Introduction to Neutron Coincidence Counter Design Based on Boron-10. Technical Report PNNL-21090. Pacific Northwest National Laboratory, Richland, WA.

Lintereur AT, ER Siciliano, and RT Kouzes. 2012. Boron-10 Lined Proportional Counter Model Validation. Technical Report PNNL-21501. Pacific Northwest National Laboratory, Richland, WA.

PANDA. 1991. Passive Nondestructive Assay of Nuclear Materials (PANDA), Nuclear Regulatory Commission NRC-FIN-A7241. Los Alamos National Laboratory Report LA-UR-90732. Available at http://www.lanl.gov/orgs/n/n1/panda/index.shtml.

Pelowitz DB (ed.). 2011. “MCNPX User’s Manual”, Version 2.7.0. Los Alamos National Laboratory Report LA-CP-11-00438.

McKinny, K, T Anderson, N Johnson, E Weissman. 2012. Presentation at the IEEE Nuclear Science Symposium, Anaheim. CA, October 29, 2012.

Menlove HO. 1981. Description and Performance Characteristics for the Neutron Coincidence Collar for the Verification of Reactor Fuel Assemblies, Los Alamos National Laboratory Report LA-8939-MS.

Menlove HO, JE Stewart, SZ Qiao, TR Wenz, PD Verrecchia. 1990. Neutron Collar Calibration and Evaluation for Assay of L WR Fuel Assemblies Containing Burnable Neutron Absorbers, Los Alamos National Laboratory Report LA-11965-MS.

Menlove HO, D Henzlova, LG Evans, MT Swinhoe, and JB Marlow. 2011. ${ }^{3}$ He Replacement for Nuclear Safeguards Applications - an Integrated Test Program to Compare Alternative Neutron Detectors. ESARDA Bulletin 46.

Rogers JL, JH Ely, RT Kouzes, AT Lintereur, and ER Siciliano. 2012. Neutron Coincidence Counting Studies. Technical Report PNNL-21686. Pacific Northwest National Laboratory, Richland, WA.

Rogers JL, JH Ely, RT Kouzes, AT Lintereur, and ER Siciliano. 2012b. Uranium Neutron Coincidence Collar Model Utilizing Boron-10 Lined Tubes. Technical Report PNNL-21750. Pacific Northwest National Laboratory, Richland, WA. 
Siciliano ER, and RT Kouzes. 2012. Boron-10 Lined Proportional Counter Wall Effects. Technical Report PNNL-21368. Pacific Northwest National Laboratory, Richland, WA.

Siciliano ER, JL Rogers, JE Schweppe, AT Lintereur, and RT Kouzes. 2012b. Uranium Neutron Coincidence Collar Model Utilizing ${ }^{3}$ He. Technical Report PNNL-21581. Pacific Northwest National Laboratory, Richland, WA. 


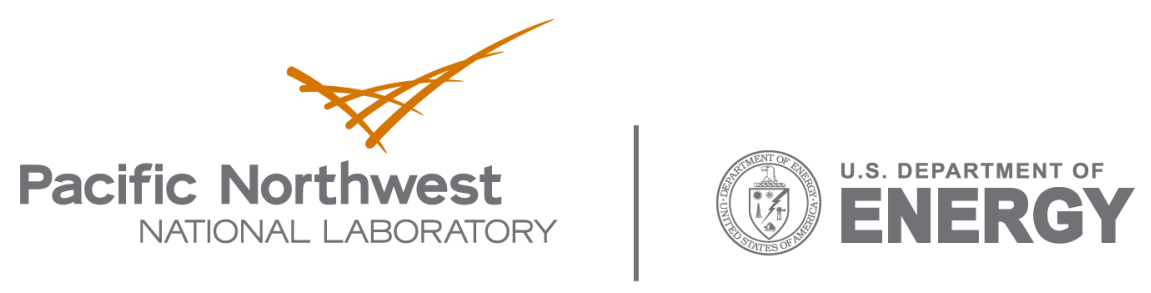

902 Battelle Boulevard

P.O. Box 999

Richland, WA 99352

1-888-375-PNNL (7665)

www.pnl.gov 